\title{
Hanford Permanent Isolation \\ Barrier Program: Asphalt Technology \\ Data and Status Report - FY 1994
}

H. D. Freeman

R. A. Romine

A. H. Zacher

September 1994

Prepared for the

U.S. Department of Energy under

Contract DE-AC06-76RLO 1830

Pacific Northwest Laboratory

Richland, Washington 99352 


\section{DISCLAIMER}

This report was prepared as an account of work sponsored by an agency of the United States Government. Neither the United States Government nor any agency thereof, nor any of their employees, make any warranty, express or implied, or assumes any legal liability or responsibility for the accuracy, completeness, or usefulness of any information, apparatus, product, or process disclosed, or represents that its use would not infringe privately owned rights. Reference herein to any specific commercial product, process, or service by trade name, trademark, manufacturer, or otherwise does not necessarily constitute or imply its endorsement, recommendation, or favoring by the United States Government or any agency thereof. The views and opinions of authors expressed herein do not necessarily state or reflect those of the United States Government or any agency thereof. 


\section{DISCLAIMER}

Portions of this document may be illegible in electronic image products. Images are produced from the best available original document. 


\section{Summary}

The asphalt layer within the Hanford Permanent Isolation Barrier (HPIB) is an important component of the overall design. This layer provides a RCRA equivalent backup to the overlying earthen layers in the unlikely event that these layers are not able to reduce the infiltration rate to less than $0.05 \mathrm{~cm} / \mathrm{yr}$. There is only limited amount of information on using asphalt for a moisture infiltration barrier over the long times required by the HPIB. Therefore, a number of activities are under way, as part of the Barrier Development Program, to obtain data on the performance of asphalt as a moisture barrier in a buried environment over a 1000-year period. These activities include 1) determining RCRA equivalency, 2) measurement of physical properties, 3) measurement of aging - characteristics, and 4) relationship to ancient asphalt analogs. During FY 1994 progress was made on all of these activities. Studies were conducted both in the laboratory and on the prototype barrier constructed over the 216-B-57 crib in the 200 East Area on the Hanford Site. This report presents results obtained from the asphalt technology tasks during FY 1994. Also included are updates to planned activities for asphalt analogs and monitoring the asphalt test pad near the prototype barrier.

Measurements of hydraulic conductivity on the HMAC portion of the prototype barrier show that the asphalt layers easily meet the RCRA standard of $1 \times 10^{-7} \mathrm{~cm} / \mathrm{s}$. In-place measurements using a new field falling head technique show an average of $3.66 \times 10^{-8} \mathrm{~cm} / \mathrm{s}$, while cores taken from the north end of the prototype and measured in a laboratory setup averaged $1.29 \times 10^{-9} \mathrm{~cm} / \mathrm{s}$. Measurements made on the fluid applied asphalt membrane (polymer-modified asphalt) show an extremely low permeability of less than $1 \times 10^{-11} \mathrm{~cm} / \mathrm{s}$. Additional hydraulic conductivity measurements using sealed double ring infiltrometers (SDRI) are currently under way to determine the hydraulic conductivity of the asphalt test pad. Results of the SDRI tests will be compared with nearby measurements using the field falling head permeameters. The use of these smaller devices has provided a simpler and faster way of determining RCRA compliance for low permeability liners and covers.

Asphalt artifacts and natural asphait analog samples were studied in the effort to establish the longterm durability of modern, man-made asphaltic materials used in the construction of the HPIB. A series of radiocarbon-dated asphalt archaeological artifacts were chemically characterized to monitor changes in the chemical composition as a function of time. The techniques used to evaluate the artifacts, high-pressure liquid chromatography and quantitative functional group analysis by fourier transform infrared, were successful at characterizing changes in the chemical composition and providing the initial data verifying the use of ancient artifacts to characterize long-term chemical properties. 


\section{Contents}

Summary $\ldots \ldots \ldots \ldots \ldots \ldots \ldots \ldots \ldots \ldots \ldots \ldots \ldots \ldots \ldots \ldots \ldots \ldots \ldots$

Abbreviations $\ldots \ldots \ldots \ldots \ldots \ldots \ldots \ldots \ldots \ldots \ldots \ldots \ldots \ldots \ldots \ldots \ldots \ldots \ldots$

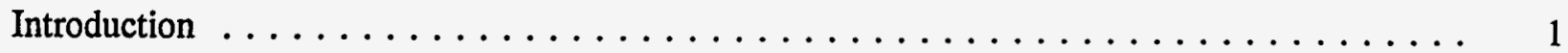

Prototype Barrier Monitoring $\ldots \ldots \ldots \ldots \ldots \ldots \ldots \ldots \ldots \ldots \ldots \ldots$

Nuclear Density Measurements $\ldots \ldots \ldots \ldots \ldots \ldots \ldots \ldots$

Field Hydraulic Conductivity Measurements . . . . . . . . . . . . . 4

Field Measurement Procedures $\ldots \ldots \ldots \ldots \ldots \ldots \ldots \ldots \ldots \ldots \ldots \ldots \ldots \ldots$

Results of Field Measurements $\ldots \ldots \ldots \ldots \ldots \ldots \ldots \ldots \ldots \ldots$

Laboratory Hydraulic Conductivity Measurements . . . . . . . . . . . . . 9

Laboratory Measurement Procedures . . . . . . . . . . . . . . . 9

Results of Laboratory Measurements $\ldots \ldots \ldots \ldots \ldots \ldots \ldots \ldots$

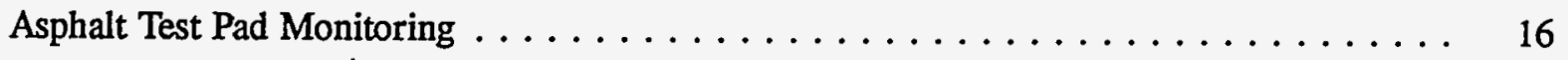

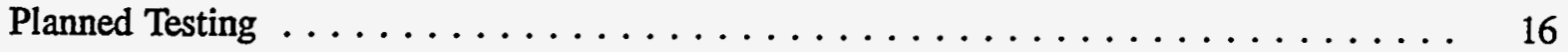

Baseline Asphalt Properties $\ldots \ldots \ldots \ldots \ldots \ldots \ldots \ldots \ldots$

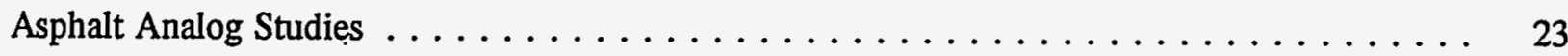

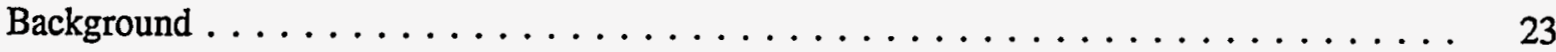

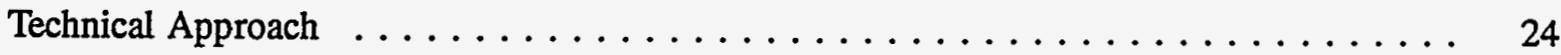

Selecting Archaeological and Neat Asphalt Samples . . . . . . . . . . . . 24

Determining the Duration of Internment for Asphalt Artifacts $\ldots \ldots \ldots \ldots \ldots$

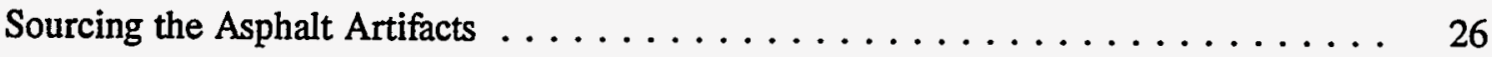

Chemical Analysis of Archaeological Asphalt to Determine the Effects of Aging . . . . 26

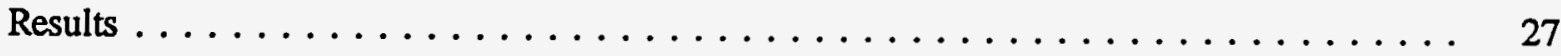

Radiocarbon Dating . . . . . . . . . . . . . . . . . 27

Elemental Analysis $\ldots \ldots \ldots \ldots \ldots \ldots \ldots \ldots \ldots \ldots \ldots \ldots \ldots$

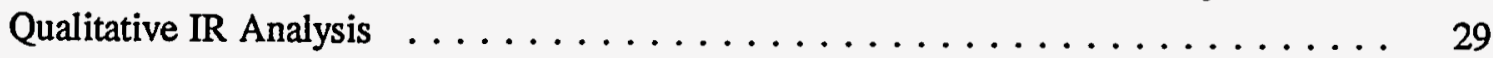


Quantitative IR Analysis . . . . . . . . . . . . . . . . . . . . . 29

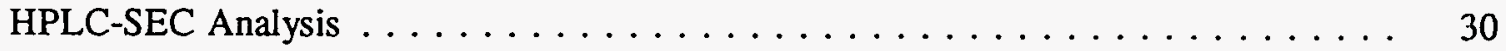

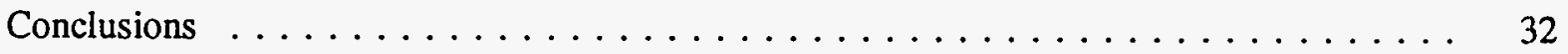

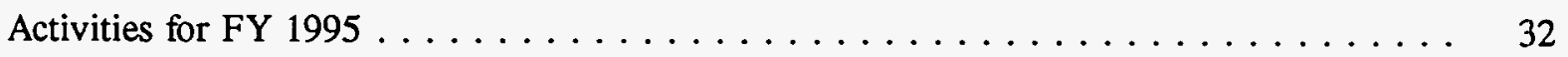

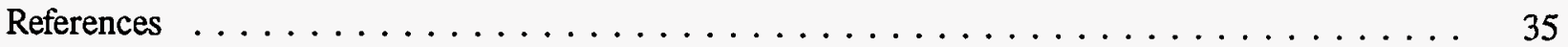




\section{Figures}

1 Cross Section of Prototype Permanent Isolation Surface Barrier $\ldots \ldots \ldots \ldots$

2 Cross Section of Asphalt Layer of Prototype Barrier . . . . . . . . . . . . 4

3 Locations of Nuclear Density Measurements . . . . . . . . . . . . . 5

4 Schematic of Field Falling Head Permeameter $\ldots \ldots \ldots \ldots \ldots \ldots \ldots$

5 Original Surface Mount FFHP Design $\ldots \ldots \ldots \ldots \ldots \ldots \ldots \ldots \ldots$

6 FFHP Used to Measure Hydraulic Conductivity on Prototype Barrier . . . . . . . . . . 8

7 Diagram of Laboratory Hydraulic Conductivity Test Setups $\ldots \ldots \ldots \ldots \ldots$

8 Change in Hydraulic Conductivity with Measurement Duration . . . . . . . . . 12

9 Change in Water Height with Change in Barometric Pressure $\ldots \ldots \ldots \ldots \ldots$

10 Effect of Temperature Change on Change in Water Column Height $\ldots \ldots \ldots$

11 Change in Hydraulic Conductivity with Measurement Duration for FAA Samples . . . . . 14

12 Hydraulic Conductivity vs. Asphalt Content for Laboratory Specimens . . . . . . . . . 15

13 Construction Details and Measurement Locations on Asphalt Test Pad . . . . . . . 16

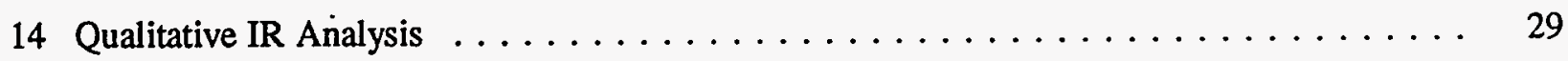

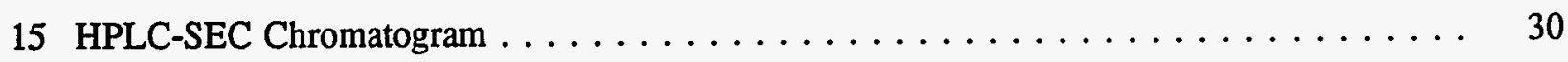

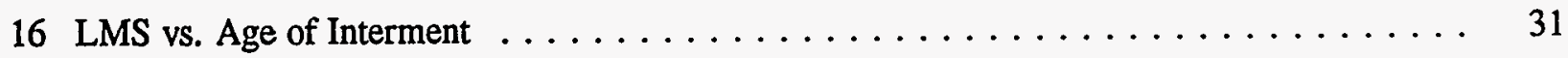




\section{Tables}

1 Density of HMAC Layer of Prototype Barrier, March 24, $1994 \ldots \ldots \ldots \ldots$

2 Density of HMAC Layer of Prototype Barrier, March $28,1994 \ldots \ldots \ldots \ldots$

3 Hydraulic Conductivity of HMAC Layer of Prototype Barrier . . . . . . . . . . 9

4 Summary of Hydraulic Conductivity Data for Prototype HMAC Cores . . . . . . . . 11

5 Hydraulic Conductivity of Fluid Applied Asphalt Membrane Samples from

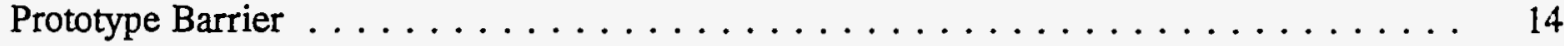

6 Hydraulic Conductivity Data for Laboratory Specimens $\ldots \ldots \ldots \ldots \ldots$

7 Mass Change After Thin Film Oven Test Conditioning . . . . . . . . . . . . . 20

8 Asphalt Binder Viscosity as Measured with Brookfield Viscometer . . . . . . . . . . 20

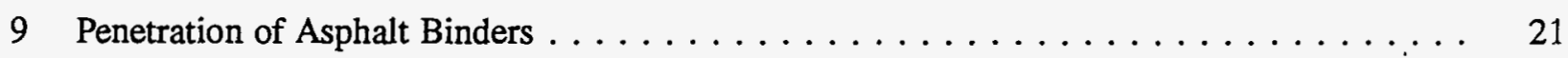

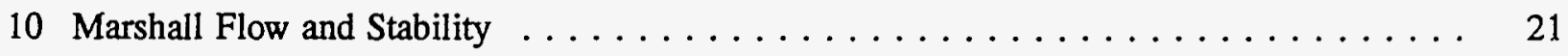

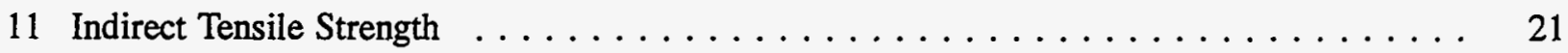

12 Radiocarbon Dates of Chumash Artifacts .................... 27

13 Elemental Analysis of Asphait Analog and Artifact Samples . . . . . . . . . . 28 


\section{Abbreviations}

AAD-1

AAG-1

AAK-1

AAM-1

B.P.

DMA

FAA

FFHP

HMAC

HDPE

HPIB

HPLC-SEC

IR

LMS

$\mathrm{Ni} / \mathrm{V}$

RCRA

PNL

SDRI

SHRP-MRL

TFOT

TLA

WHC
SHRP-MRL AR-4000 asphalt derived from California coastal crude oils SHRP-MRL AR-4000 graded asphalt derived from California Valley crude oils SHRP-MRL AC-30 graded asphalt derived from Boscan, Venezuela crude oil SHRP-MRL AC-20 grade asphalt derived from West Texas Intermediate crude oil

Before Present

dynamic mechanical analysis

fluid applied asphalt

field falling head permeameter

hot-mix asphalt concrete

high density poly(ethylene)

Hanford Permanent Isolation Barrier

high pressure liquid chromatography - size exclusion chromatography

infrared spectroscopy

large molecular size

nickel/vanadium

Resource Conservation and Recovery Act of 1976

Pacific Northwest Laboratory

sealed double ring infiltrometers

Strategic Highway Research Program - Materials Reference Library

thin film oven test

Trinidad Lake asphalt

Westinghouse Hanford Company 


\section{Introduction}

Certain types of waste at the Hanford Site (and elsewhere) may be disposed of using in-place stabilization techniques. Much of the waste that would be disposed of by in-place stabilization is now located in relatively shallow subsurface structures such as solid waste burial grounds, tanks, vaults, and cribs. Many of these in-place stabilization scenarios will require the use of a surface barrier to minimize the infiltration of water into the waste.

The Hanford Site Permanent Isolation Barrier Development Program was organized to develop the technology needed to provide a long-term surface barrier capability for the Hanford Site. This technology could also be adapted to other sites. The program, which is divided into several tasks, is being jointly conducted by Pacific Northwest Laboratory (PNL) ${ }^{(a)}$ and Westinghouse Hanford Company (WHC) and is sponsored by the U.S. Department of Energy's Environmental Restoration Program.

Permanent isolation barriers use engineered layers of natural materials to create an integrated structure with redundant protective features. Low-permeability layers, which are placed in the barrier profile below the primary earthen layers, divert from the waste zone any percolating water that gets through the earthen cover. Furthermore, they limit the upward movement of noxious gases from the waste zone (Terrel 1991). The coarse materials located above the low-permeability layers also serve as a drainage medium to channel any percolating water to the edges of the barrier.

A composite asphalt barrier (fluid-applied polymer-modified/asphalt-aggregate mixture is being considered as an alternative to the RCRA $^{(\mathfrak{b})}$ bentonite clay/high density poly(ethylene) (HDPE) barriers for the low-permeability component of the Hanford Permanent Isolation Barrier (HPIB). It is believed, if not fairly well accepted, that HDPE liners and clay barriers will be incapable of performing over the proposed design life of most surface barriers. Asphalt, on the other hand, appears to be capable of performing to specification over the 1000-year design life criterion. The complex chemistry of asphalt is perhaps its biggest advantage over most other construction materials.

Natural asphalt, or bitumen, has been used for a documented 5000 years, and may have been used by prehistoric peoples for a considerably longer period. Available worldwide in surface or readily accessible deposits, asphalt is a transitional phase in the evolution of crude oil, in which lighter, volatile fractions have been removed through evaporation, mechanical processes, thermal alteration, or high pressure (Hellmuth 1989). The state of the material's evolution, differences in the composition of the parent material, and the process(s) to which it has been subjected all account for the extreme variability found in the physical and chemical characteristics of asphalts. Asphalts from a majority of sources share common features, however, which made them attractive to early cultures: a high degree of water repellency, lack of volatility, pronounced adhesiveness, impermeability, and longevity. These same properties have stimulated interest in incorporating asphalt into nuclear waste containment systems.

(a) Operated for the U.S. Department of Energy by Battelle Memorial Institute under Contract DE-AC06-76RLO 1830.

(b) Resource Conservation and Recovery Act of 1976. 
A composite asphalt barrier was selected for use in the HPIB for several reasons. Low air void, high-asphalt-content, hot-mix asphalt concretes (HMAC) are noted for low permeability and improved mechanically stable compositions. HMAC exhibits a range of permeabilities and physical stability characteristics (Terrel 1991; Tuffour and Ishai 1990; Periasamy et al. 1990). The higher the asphalt content, the lower the permeability and the better the physical stability. At asphalt contents above $20 \mathrm{wt} \%$, asphalt/aggregate mixes (concrete) were shown to be extremely effective in controlling radon emanation from uranium mill tailings (Hartley et al. 1981; Gee et al. 1989). Liners with high asphalt content also have been tested successfully and shown to minimize leachate losses from stored liquid wastes (Buelt et al. 1981). Furthermore, HMAC is a widely used construction material with welldocumented engineering properties and construction techniques. The construction technology is already deployed and readily available for large-scale testing and demonstration.

Measuring or estimating physical degradation rates of the asphalt components of the HPIB is required to establish a confidence level in long-term barrier performance. Changes in properties such as shear modulus, elasticity, and permeability need to be known, and data bases provide a baseline to estimate changes in these properties for asphalt layers for the extremely long durations specified.

An asphalt test pad is located north of a prototype HPIB barrier constructed on the Hanford Site (Wing 1993; Gee et al. 1993). The test pad was built to allow the HMAC to be monitored after the asphalt in the prototype had been covered. Because this test pad is located over a clean site it can also be destructively sampled without fear of providing a path to contaminated areas. The test pad consists of two lifts of asphalt identical to that placed on the prototype barrier. The test pad covers an area of $160 \mathrm{~m}^{2}(8.6 \mathrm{~m} \mathrm{x} 18.6 \mathrm{~m})$ and is built over a $7.5 \mathrm{~m} \mathrm{x} 7.5 \mathrm{~m}$ pan lysimeter to monitor any infiltration through the barrier.

The work conducted in FY 1994 involved a combination of field and laboratory studies. These studies were divided into three primary areas: 1) support for the construction of the prototype barrier, 2) laboratory studies of HMAC and asphalt binder to determine long-term performance of asphalt barriers, and 3) studies of ancient asphalt analogs to provide supporting data predicting long-term performance of asphalt barriers. This report documents the results obtained to date for these three areas. Also included is a description of planned activities for measurements on the asphalt test pad and additional work required to complete the asphalt analog studies. 


\section{Prototype Barrier Monitoring}

A prototype barrier of the HBIP covering approximately 0.65 hectares was constructed at the 200-BP-1 operable unit over the B-57 crib during the spring and summer of 1994 . Details of this prototype barrier can be found in Wing (1993) and Gee et al. (1993). A cross section is shown for reference in Figure 1. The asphalt layer was placed at the bottom on a 2 degree slope to the east and west and level to the north and south. The asphalt was terraced as shown in Figure 2 to allow collection of water from different portions of the barrier through a series of metal gutters and collection pipes, which are routed through water measurement siphons. The water is ultimately collected in a storage pond to the north of the barrier. The asphalt barrier consists of two courses of $7.5-\mathrm{cm}$ compacted HMAC containing $\sim 7.5 \mathrm{wt} \%$ asphalt placed with overlapping seams to minimize the possibility of creating a pathway to the underlying soil.

The monitoring activities consisted of several measurements to provide a framework for determining the effectiveness of the asphalt barrier. These measurements included nuclear density and hydraulic conductivity. A test pad $\sim 8.6 \times 18.6 \mathrm{~m}$ was also constructed north of the prototype to provide an area to conduct longer-term testing since the asphalt layer in the prototype would only be accessible for a short time before it was covered with the other barrier layers. A $7.5 \mathrm{~m} \times 7.5 \mathrm{~m}$ pan lysimeter was placed beneath the asphalt at the northeast corner of the prototype and also directly beneath the asphalt test pad.

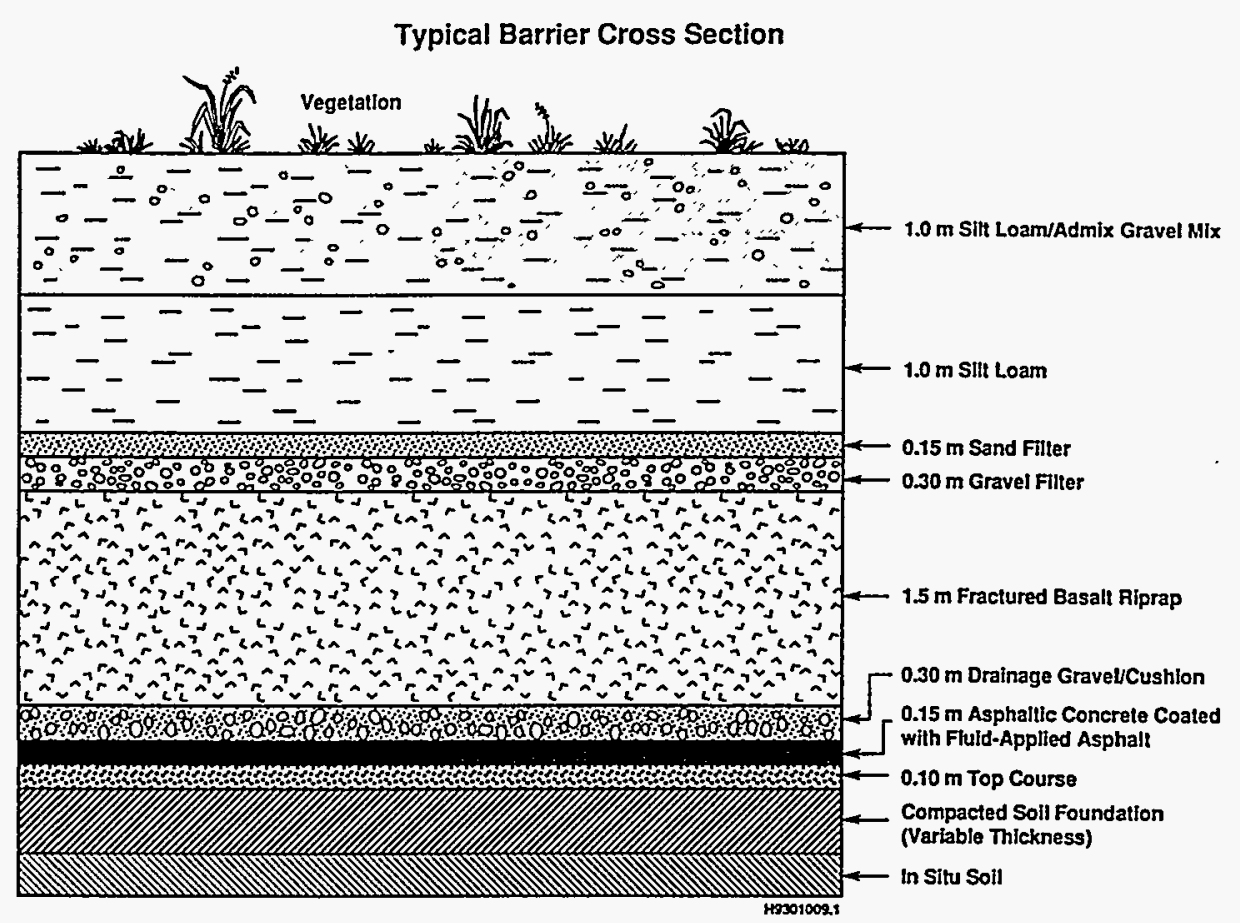

Figure 1. Cross Section of Prototype Permanent Isolation Surface Barrier 


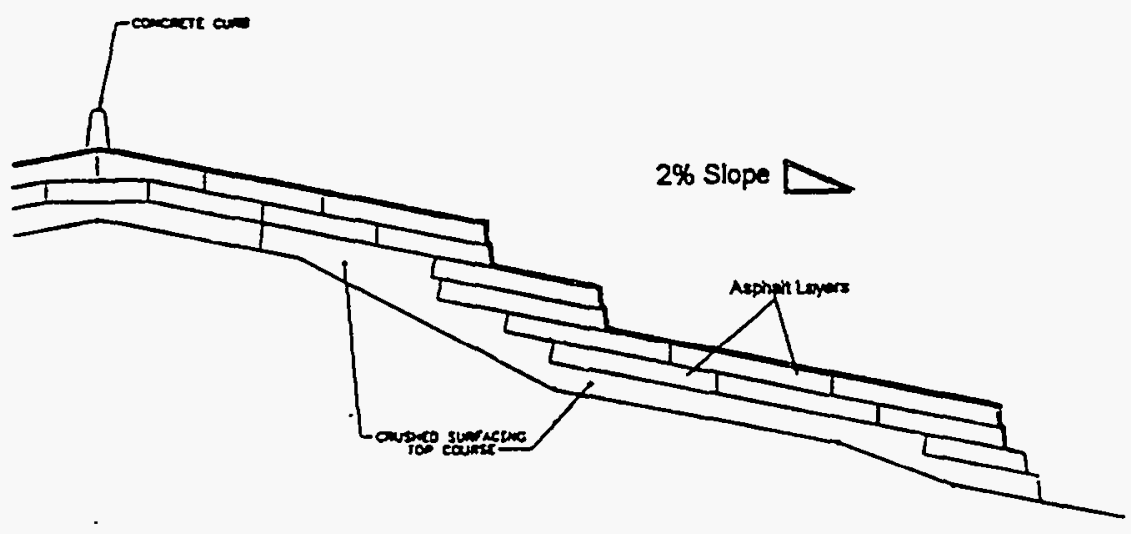

Figure 2. Cross Section of Asphalt Layer of Prototype Barrier. Note: vertical scale is exaggerated.

\section{Nuclear Density Measurements}

The density of the HMAC is a critical property of the barrier that relates to the amount of air voids and is directly correlated to the hydraulic conductivity of the layer. The density of the HMAC layer of the prototype was measured at a number of locations with a Seaman nuclear density gauge. This is a nondestructive technique used routinely in the asphalt paving industry.

Approximate locations for the measurements are shown in Figure 3, and results of the measurements are presented in Tables 1 and 2. Results of these measurements show that a compaction of greater than $95 \%$ of the theoretical maximum density $\left(151 \mathrm{lb} / \mathrm{ft}^{3}\right)($ ASTM D2041) was achieved. The uniformity of the density measurements were within accepted construction practices across the barrier.

\section{Field Hydraulic Conductivity Measurements}

Originally, field hydraulic conductivity measurements were planned only for the asphalt test pad because of the short time between HMAC installation and subsequent application of the overlying layers. However, it was discovered during routine analysis of grab samples from the asphalt paver that the size distribution of the aggregate in the HMAC mix was slightly out of specification. The HMAC samples were low in fines content and occasionally high in \#4 aggregate.

These small discrepancies in aggregate gradation were not expected to significantly affect barrier performance. The impact of the out-of-specification mix could be determined by measuring the hydraulic conductivity of the HMAC layer of the barrier to see if it met the RCRA guideline of $1 \times 10^{-7} \mathrm{~cm} / \mathrm{s}$. This was accomplished by two separate methods. First, core samples were taken at the north end of the prototype in 12 locations. Laboratory hydraulic conductivity measurements were made on five of these cores. Second, a new field falling head permeability measurement technique was developed and used on the prototype in five locations on the north end. 


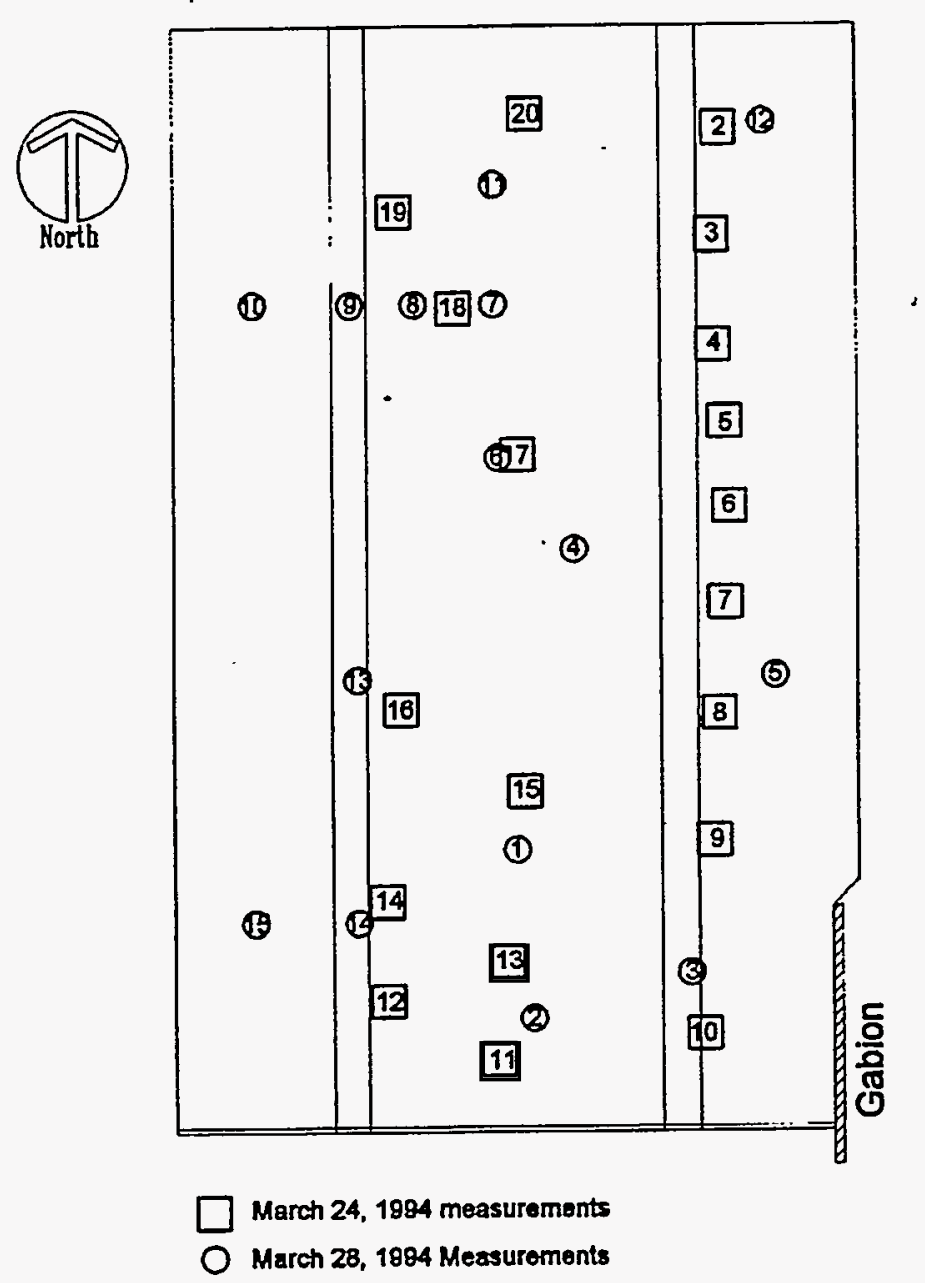

Figure 3. Locations of Nuclear Density Measurements

Table 1. Density of HMAC Layer of Prototype Barrier, March 24, 1994

\begin{tabular}{cccc} 
Location & Bulk Density, $\mathbf{l b} / \mathbf{f t}^{\mathbf{3}}$ & Location & Bulk Density, lb/ \\
\hline 2 & 140.9 & 12 & 146.3 \\
3 & 144.3 & 13 & 148.6 \\
4 & 131.5 & 14 & 146.3 \\
5 & 143.0 & 15 & 146.9 \\
6 & 143.6 & 16 & 146.9 \\
7 & 144.0 & 17 & 150.9 \\
8 & 145.9 & 18 & 148.0 \\
9 & 142.9 & 19 & 147.2 \\
10 & 142.0 & 20 & 147.4 \\
11 & 148.9 & Average \pm SD & $145.0 \pm 4.2$
\end{tabular}


Table 2. Density of HMAC Layer of Prototype Barrier, March 28, 1994

\begin{tabular}{|c|c|c|c|c|c|}
\hline \multicolumn{3}{|c|}{ Density, lb/ft ${ }^{3}$} & \multicolumn{3}{|c|}{ Density, $\mathbf{l b} / \mathbf{f t}^{3}$} \\
\hline Location & $\mathbf{A}$ & $\overline{\mathbf{B}^{(2)}}$ & Location & $\mathbf{A}$ & $\overline{\mathbf{B}^{(2)}}$ \\
\hline 1 & 151.0 & 148.2 & 9 & 148.2 & 148.5 \\
\hline 2 & 149.8 & 149.9 & 10 & 147.6 & 146.5 \\
\hline 3 & 145.1 & 143.2 & 11 & 146.2 & 143.2 \\
\hline 4 & 141.3 & 143.1 & 12 & 146.5 & 145.7 \\
\hline 5 & 150.0 & 151.3 & 13 & 149.7 & 149.2 \\
\hline 6 & 147.1 & 145.3 & 14 & 143.9 & 146.2 \\
\hline 7 & 148.5 & 147.9 & 15 & 146.9 & 146.9 \\
\hline 8 & 146.3 & 146.6 & Average $\pm S D$ & $147.2 \pm 2.5$ & $146.8 \pm 2.5$ \\
\hline
\end{tabular}

(a) Measurement $\mathrm{B}$ was made at a 90 degree angle to measurement $\mathrm{A}$.

As discussed above, hydraulic conductivity measurements of the five locations on the north end of the prototype barrier were made to resolve the concerns about the performance of the HMAC. Before these measurements could be carried out, a method of determining if the HMAC would perform as designed (minimum of $1 \times 10^{-7} \mathrm{~cm} / \mathrm{s}$ ) was needed that would not significantly impact the construction schedule. Ordinarily, sealed double ring infiltrometers (SDRI) would be used, but this technique could take as long as several months to set up and achieve equilibrium. Instead, a method was devised to obtain accelerated results from somewhat smaller areas than typically measured with SDRIs. This method was adapted for use in the field, based on standard laboratory falling head permeability tests, which allow measurement of $10^{-7} \mathrm{~cm} / \mathrm{s}$ hydraulic conductivity in a matter of days instead of weeks.

\section{Field Measurement Procedures}

The field falling head permeameter (FFHP) consists of a reservoir, which defines the area of measurement, and a standing pipe used to apply a head of water. Figure 4 illustrates the basic design of the apparatus. The apparatus is attached to the surface of the barrier/liner by one or a combination of the following techniques:

- flange bolted to surface

- weighted to surface and/or

- sealed into a surface groove.

The method selected for attaching the reservoir to the surface depends on the type of materials being evaluated. Figure 5 illustrates the original reservoir design, which could be used where intrusion into the barrier is not desired and a water-tight seal can be obtained between the flange and the surface of the barrier.

At the prototype barrier, some difficulty was encountered when trying to seal the flange to the surface of the HMAC. Apparently there is enough surface porosity to allow lateral migration of water under the seal. This migration is enhanced by the relatively large $(2 \mathrm{~m})$ water column used for the measurement. It was necessary to counterweight the reservoir with lead bricks or other heavy objects 

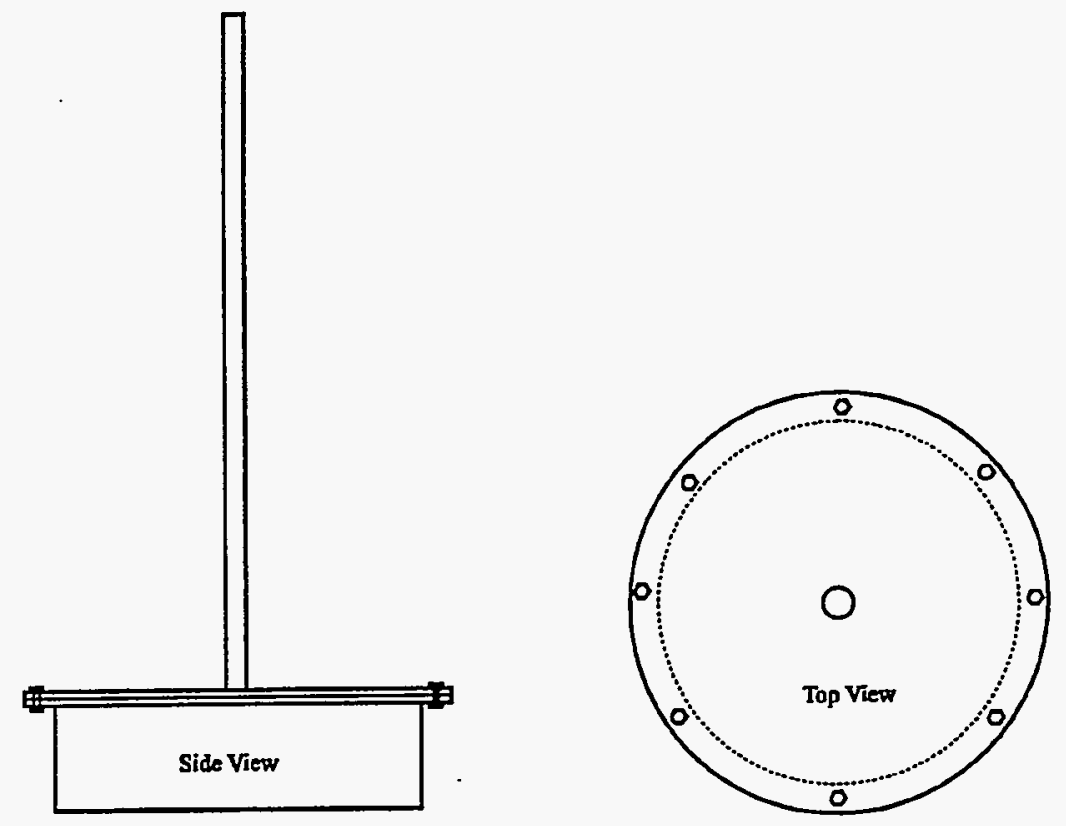

Figure 4. Schematic of Field Falling Head Permeameter

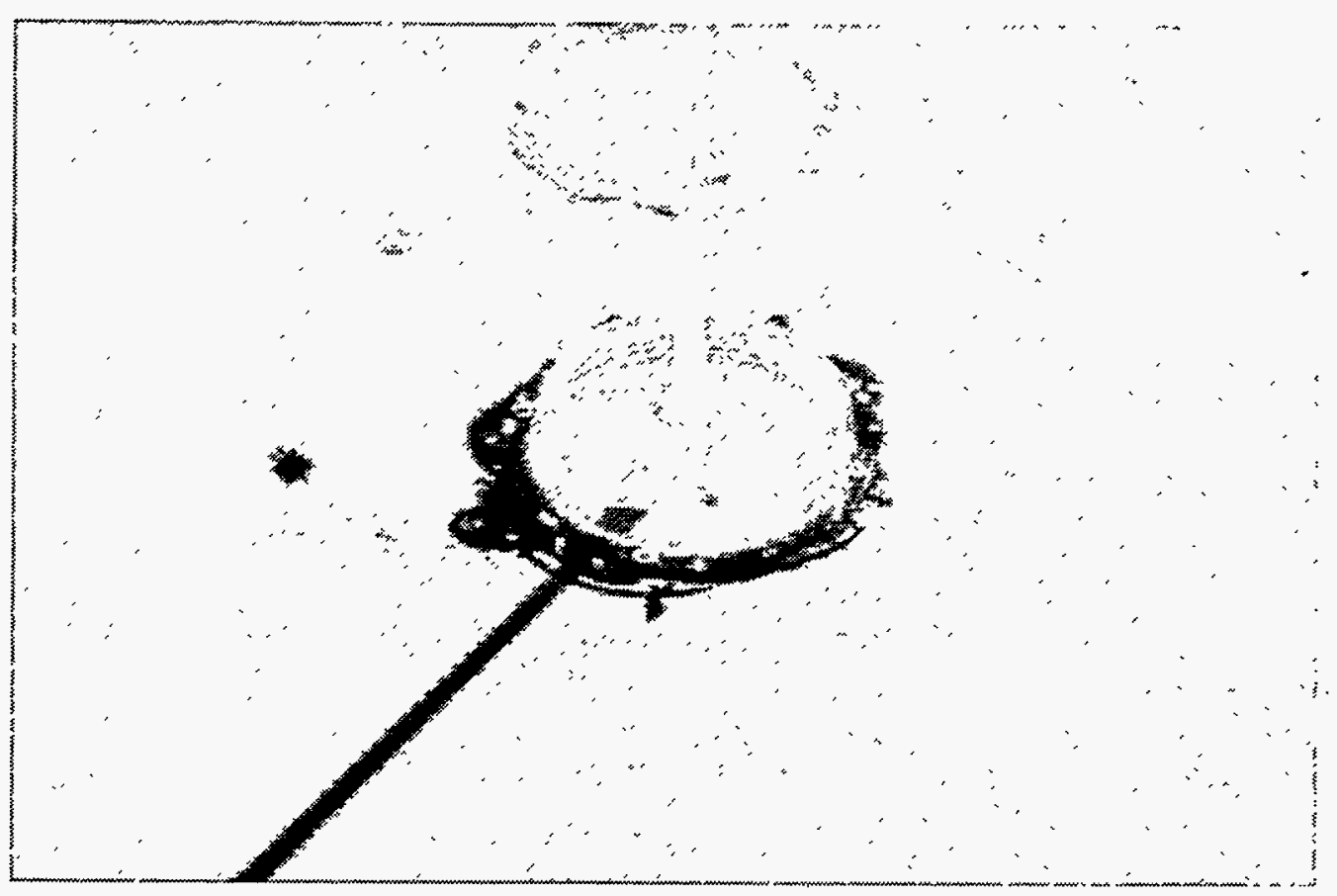

Figure 5. Original Surface Mount FFHP Design 
to keep it from lifting from the surface of the asphalt. These problems led to the development of a different system that was designed to prevent lateral migration by using a confining ring set into a groove in the asphalt. The rings are made of stainless steel with a top flange that allows the top of the reservoir and stand pipe to be bolted on with a rubber gasket as shown in Figure 6. This confining ring is sealed in a $25-\mathrm{cm}$-diameter groove, $\sim 1.25 \mathrm{~cm}$ wide and up to $10 \mathrm{~cm}$ deep, using pure bentonite clay or abantonite grout. The benonite expands when water is introduced into the FFHP, providing a good seal between the confining ring and the asphalt. About $200 \mathrm{lb}$ of counter weights are still needed to keep the ring from being pushed out of the ground from the hydraulic pressure of the water in the stand tube. The base and tube are covered with insulation to minimize the temperature fluctuations of the water in the permeameter. Large temperature changes could bias the measurement due to the expansion and contraction of water. This was minimized by taking readings at about the same time each time early in the morning and by insulating the entire assembly.

The measurement is made by sealing the system in the asphalt, adding water to the reservoir, and noting the height of the water column in the stand pipe. A second reading is taken approximately $24 \mathrm{hr}$ later, and the permeability is calculated from the following equation:

$$
K=a /(A \cdot t) \cdot L \cdot \ln (h 1 / h 2)
$$

where

$\mathrm{K}$ =hydraulic conductivity, $\mathrm{cm} / \mathrm{s}$

a $=$ cross-sectional area of stand pipe, $\mathrm{cm}^{2}$

A $=$ cross-sectional area of permeameter, $\mathrm{cm}^{2}$

$\mathrm{L}=$ thickness of barrier, $\mathrm{cm}$

h1 =initial height of water column, $\mathrm{cm}$

h2 =final height of water column, $\mathrm{cm}$

$\mathrm{t}=$ time for water to drop from $\mathrm{h} 1$ to $\mathrm{h} 2, \mathrm{~s}$.

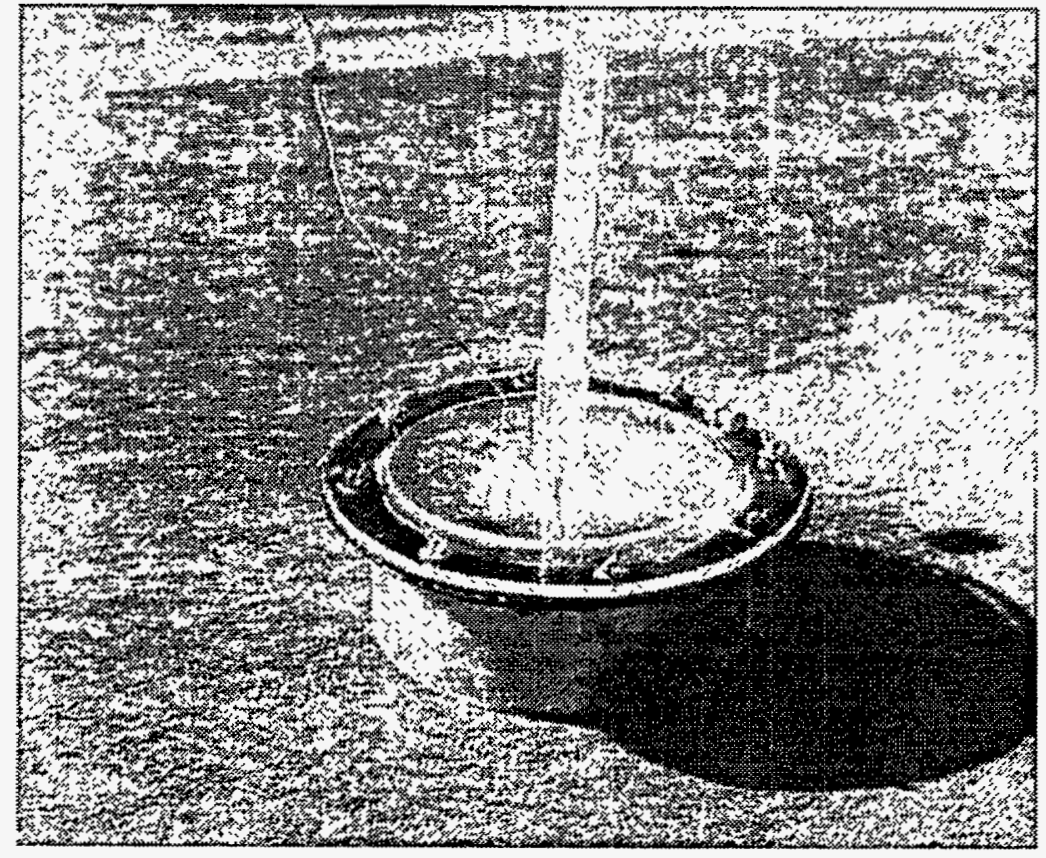

Figure 6. FFHP Used to Measure Hydraulic Conductivity on Prototype Barrier 


\section{Results of Field Measurements}

Hydraulic conductivity measurements were made at the five locations on the north end of the prototype using the FFHP shown in Figure 6. Other locations on the barrier were not measured because there were concerns about introducing defects in the asphalt over the contaminated zones. Measurements were made during a 5-day period from April 27 - May 1, 1994. Readings were taken from the permeameters on a daily basis. Not all five of the permeameters were on for the same amount of time because some small leaks were discovered between the confining ring flange and stand tube top. Results of these measurements are presented in Table 3.

The data presented in Table 3 represent a conservative estimate of the hydraulic conductivity of the HMAC component of the prototype barrier. The average of these measurements on the final day of measurement is still far below the RCRA $1 \times 10^{-7} \mathrm{~cm} / \mathrm{s}$ goal. At least two factors make these conservative estimates. First, the bentonite clay, sealing the FFHP, did not have time to fully hydrate. Since the clay was still hydrating, part of the drop in water in the stand tube was due to the uptake of water. Second, the confining ring only penetrated $5 \mathrm{~cm}$ into the asphalt. Once any water passes below this point it is no longer.horizontally confined, which increases the effective area of the measurement.

\section{Laboratory Hydraulic Conductivity Measurements}

Laboratory hydraulic conductivity measurements made in FY 1994 included laboratory-preparedmix design specimens, field core samples from the prototype barrier, and fluid applied asphalt (FAA) membrane samples obtained during application of the FAA layer. These measurements were made using conventional constant and falling head techniques modified to measure very low infiltration rates of water into the specimens. A schematic of the two types of setups used is shown in Figure 7.

\section{Laboratory Measurement Procedures}

In early FY 1994, the constant head technique, where the pressure of water above the sample is kept constant, was used to measure hydraulic conductivity. The advantage of this method is that the applied head could be increased beyond that easily obtainable from falling head techniques where a column of water open to the atmosphere is used to provide the gradient for water movement through the sample.

Table 3. Hydraulic Conductivity of HMAC Layer of Prototype Barrier, $\mathrm{cm} / \mathrm{s}$

\begin{tabular}{cccccc} 
Location & 27-Apr & 28-Apr & 29-Apr & 30-Apr & 1-May \\
\hline 1 & -- & - & $3.09 \mathrm{E}-08$ & $3.88 \mathrm{E}-08$ & $1.91 \mathrm{E}-09$ \\
2 & - & - & $3.92 \mathrm{E}-07$ & $2.16 \mathrm{E}-07$ & $1.08 \mathrm{E}-07$ \\
3 & $1.05 \mathrm{E}-07$ & $3.06 \mathrm{E}-08$ & $2.09 \mathrm{E}-08$ & $5.66 \mathrm{E}-09$ & $1.47 \mathrm{E}-08$ \\
4 & - & $9.27 \mathrm{E}-08$ & $9.69 \mathrm{E}-08$ & - & $4.33 \mathrm{E}-08$ \\
5 & - & $5.44 \mathrm{E}-08$ & $2.80 \mathrm{E}-08$ & $1.43 \mathrm{E}-08$ & $1.51 \mathrm{E}-08$
\end{tabular}



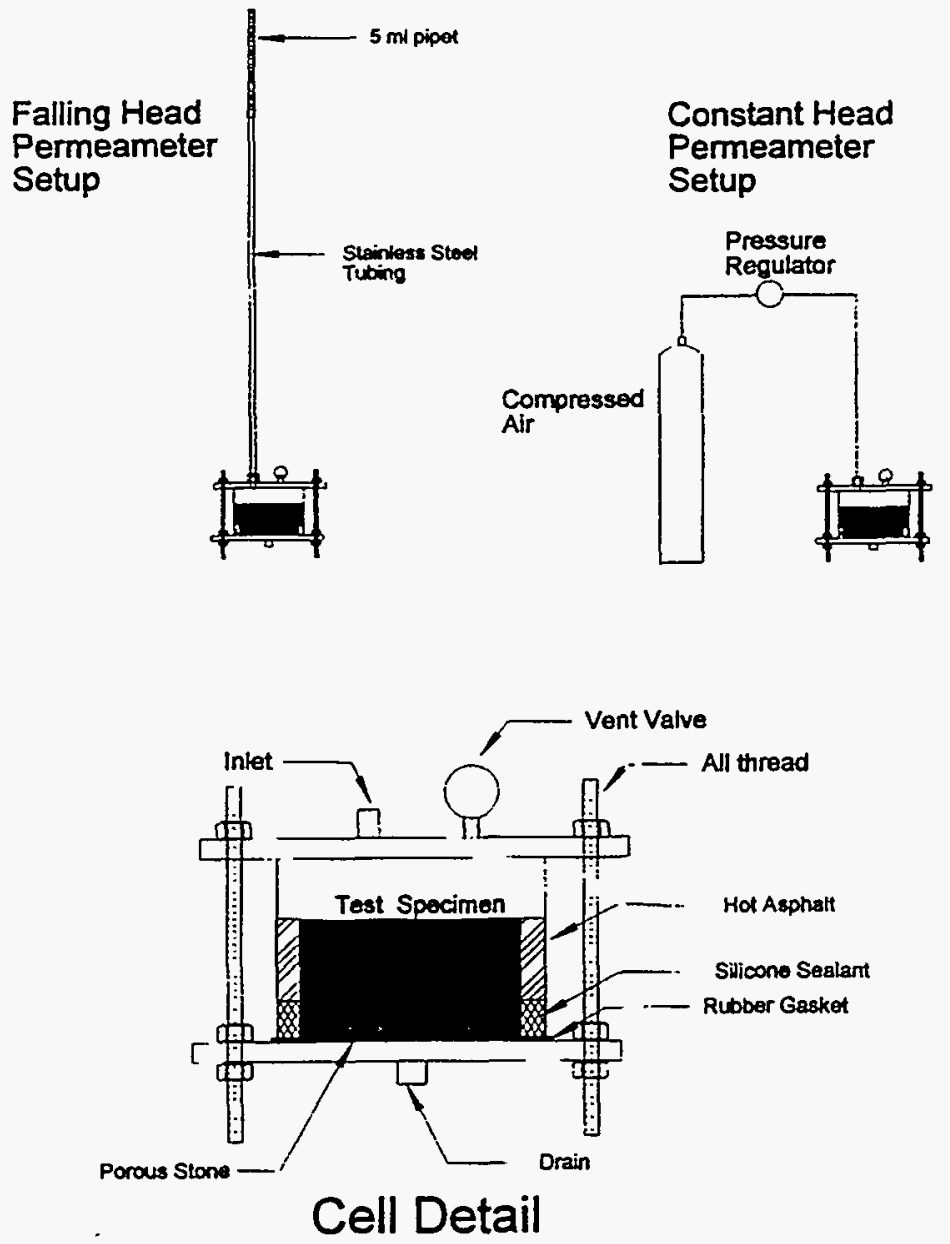

Figure 7. Diagram of Laboratory Hydraulic Conductivity Test Setups

Tests were conducted at pressures up to $30 \mathrm{psi}$; however, at higher pressures it was difficult to hold the specimen in the test cell without developing leaks between the specimen and the walls of the permeameter. The pressure for most of the constant head measurements was held at 10 psi to simulate the pressure of the overlying barrier layers on the asphalt.

After a number of measurements it was clear that the hydraulic conductivity of the HMAC was so low that breakthrough of water at the bottom of the specimen was not likely in a reasonable time frame. Therefore, all of the tests were switched to the falling head method using approximately $250 \mathrm{~cm}$ of applied head. A very small diameter $(0.25 \mathrm{~cm})$ stand pipe capped with a $5-\mathrm{mL}$ pipe was used to allow measurement of very small amounts of water into the specimens. Daily readings were taken on each permeameter and recorded in an Excel spreadsheet used to calculate the daily change in permeability. Part of the objective of the falling head permeameter measurements was to define the test procedure for low-permeability materials such as asphalt by determining the effects of temperature and barometric pressure on the variability in daily hydraulic conductivity readings. 


\section{Results of Laboratory Measurements}

Falling head permeability measurements were made on a variety of samples in support of the prototype barrier, including HMAC cores from the north end of the prototype, FAA membrane samples taken during application on the prototype, and HMAC test specimens prepared in the laboratory to investigate the effects of asphalt content and aggregate size distribution on hydraulic conductivity. In addition to these asphalt specimens, ceramic plates with known hydraulic conductivities, ranging from $10^{-5}$ to $10^{-9} \mathrm{~cm} / \mathrm{s}^{-1}$ were tested to validate the falling head technique used for this project. The results of these measurements in these three categories are presented below.

Prototype Core Samples. Twelve core samples were taken with a 10-cm rotary diamond corer under the direction of ICF Kaiser to provide samples to evaluate the effect of the off-specification aggregate present in the asphalt mix. The samples were obtained from six locations, two per location, at the north end of the prototype to avoid penetrations through the barrier over a contaminated site. Five of the cores (Samples 1A - 5A) were selected for use in hydraulic conductivity measurements. The sixth sample was too tall to fit in our modified test cells and hence was not included. The samples were sealed in the cells with silicone and hot asphalt. Results of the measurements are shown in Table 4.

Data in Table 4 show that the permeability of the HMAC component of the barrier is significantly less than that found from the FFHP measurements and even below the overall barrier goal of $1.6 \times 10^{-9}$ $\mathrm{cm} / \mathrm{s}$ (Wing 1993). The thickness of the barrier, on average, is close to the design criterion of $15 \mathrm{~cm}$. Figure 8 shows a plot of the hydraulic conductivity as a function of the measurement duration.

Figure 8 shows that there is a great amount of variability in the measurement with time. Apparently, it takes approximately 10 days before the measurements reach equilibrium. It was speculated that the variability was caused by changes in temperature or barometric pressure that caused a change in the water volume in the cell and stand pipe. This hypothesis was checked by plotting the change in water height as a function of barometric change and temperature change. These plots are presented in Figures 9 and 10. No apparent relationship is evident in Figure 9, which indicates that changes in barometric pressure are not responsible for the variability in the hydraulic conductivity measurements.

Table 4. Summary of Hydraulic Conductivity Data for Prototype HMAC Cores

\begin{tabular}{ccc} 
Sample & Thickness, $\mathbf{c m}$ & Hydraulic Conductivity, $\mathbf{c m} / \mathbf{s}$ \\
\hline 1A & 15.3 & $1.32 \mathrm{E}-09$ \\
2A & 14.8 & $3.45 \mathrm{E}-10$ \\
3A & 16.7 & $2.42 \mathrm{E}-10$ \\
4A & 17.1 & $1.24 \mathrm{E}-10$ \\
5A & 14.1 & $3.16 \mathrm{E}-10$ \\
Average & 15.6 & $4.69 \mathrm{E}-10$
\end{tabular}




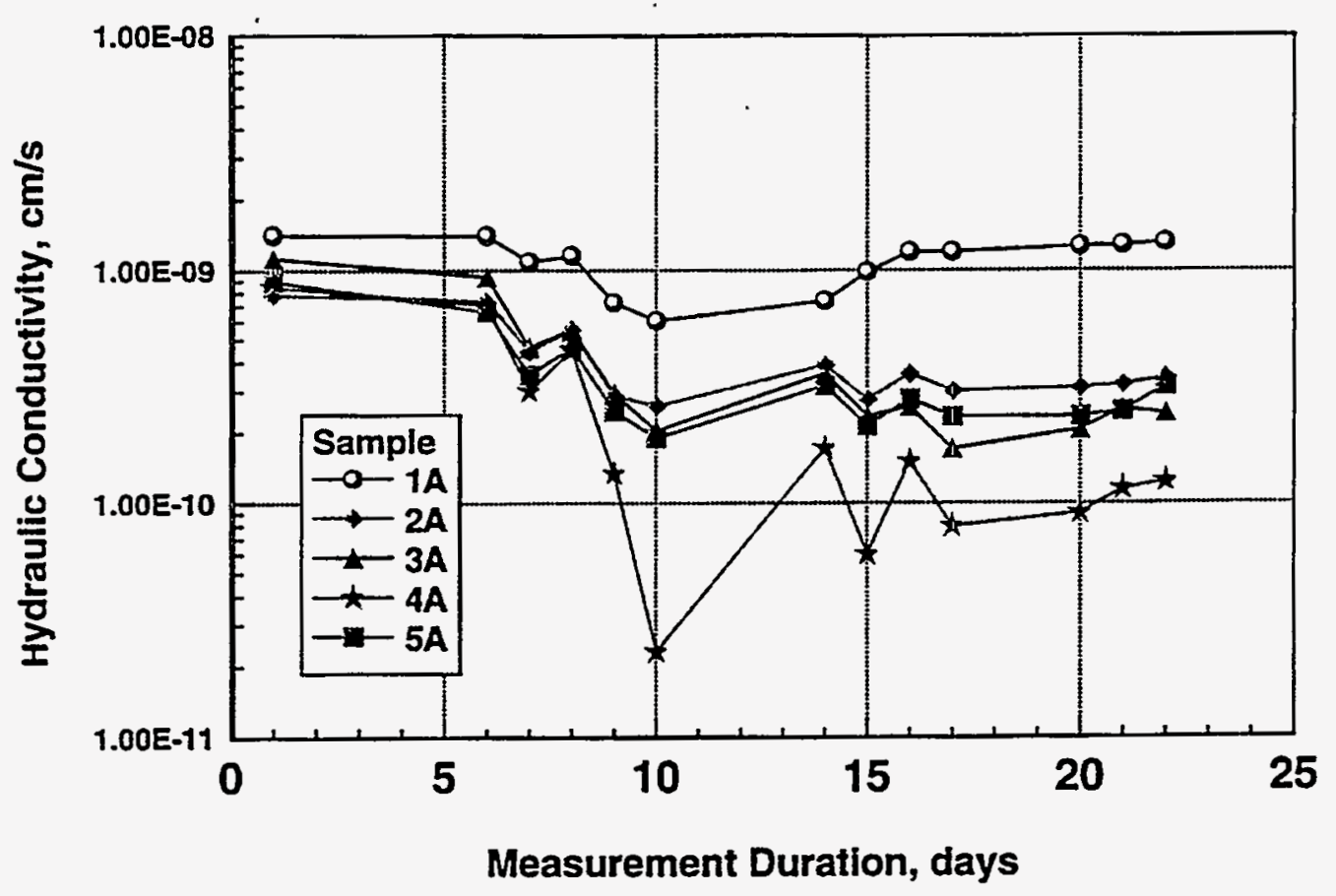

Figure 8. Change in Hydraulic Conductivity with Measurement Duration

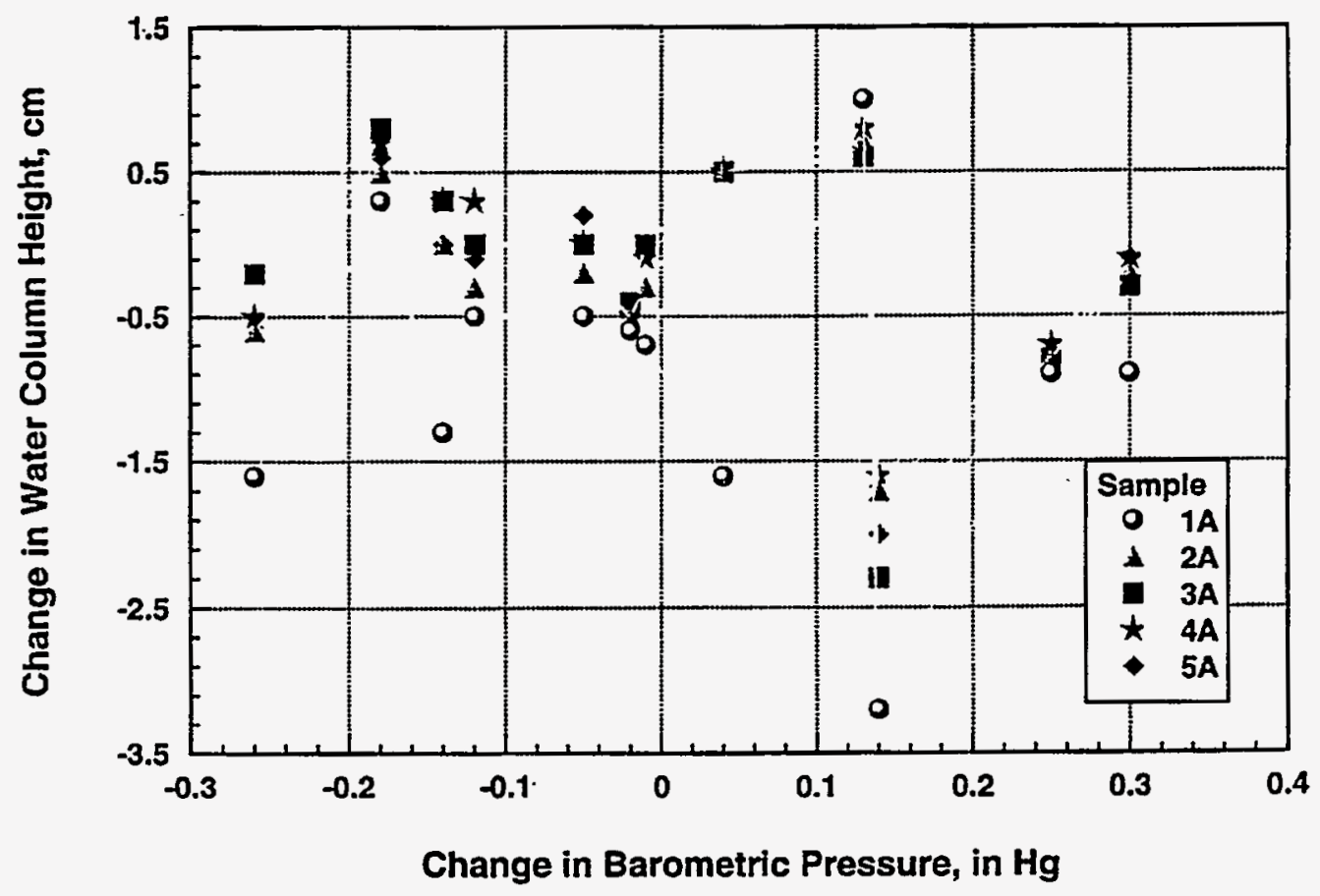

Figure 9. Change in Water Height with Change in Barometric Pressure 


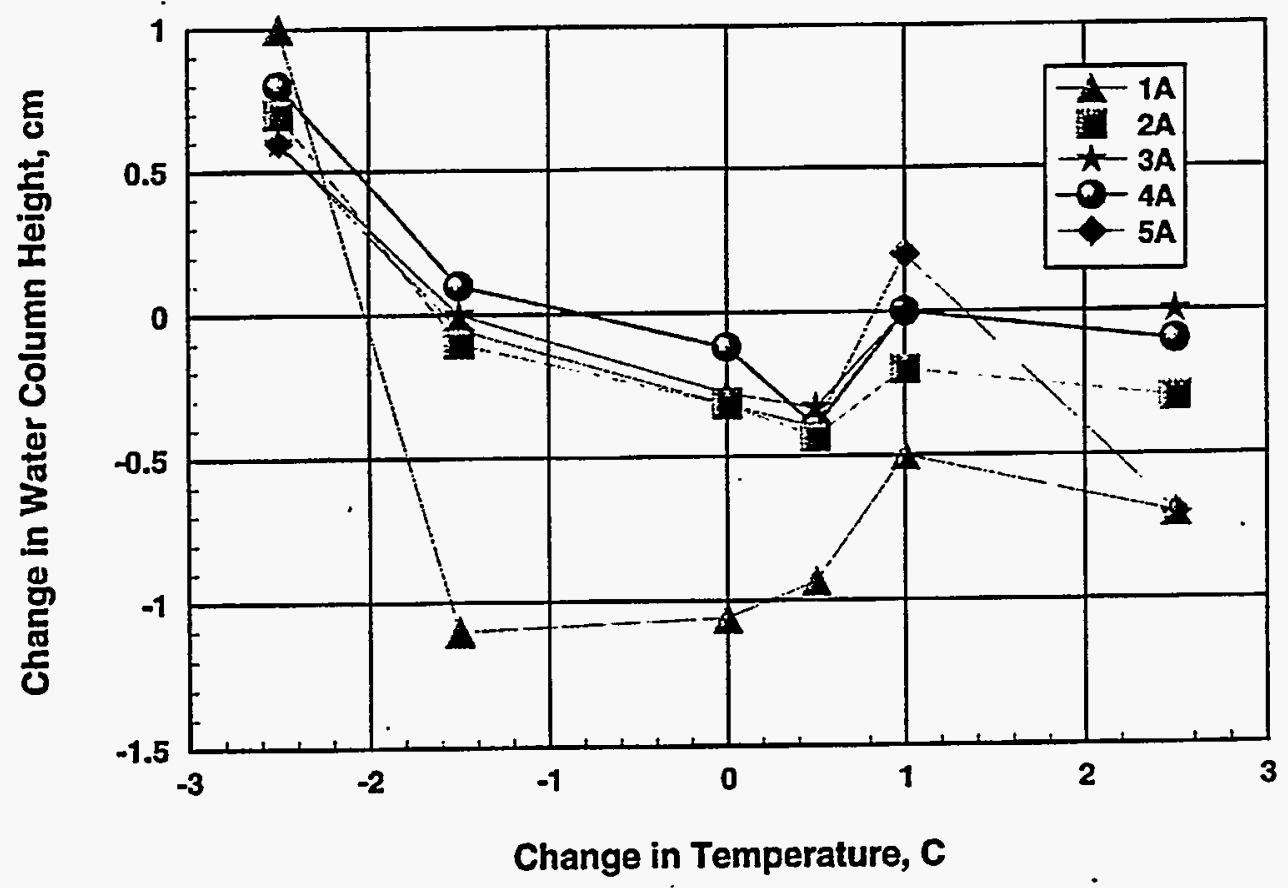

Figure 10. Effect of Temperature Change on Change in Water Column Height, $\mathrm{cm}$

There is no logical pattern revealed by Figure 10 to suggest that changes in temperature between measurement intervals significantly change the measurement. Neither barometric pressure nor temperature appears to correlate with variations in the water height from that expected at steady state. This means that other factors are the cause of the variations. For the purpose of these measurements, the daily variations are of little consequence because the hydraulic conductivity of the asphalt material is so far below the acceptance criterion.

FAA Membrane Results. The polymer-modified asphalt membrane, commonly referred to as the FAA membrane, was placed on the HMAC after $\sim 6$ weeks of cure time to allow volatile materials to escape from the mix, which minimizes bubbling of the FAA. Samples were taken from the barrier during application by placing squares of release paper on the HMAC before the FAA was applied. The squares were subsequently removed by cutting them out with a razor blade. The squares were then trimmed to $10 \mathrm{~cm}$ diameter and sealed in a permeability cell and tested according to the standard laboratory falling head methods. The results of these measurements are shown in Table 5.

The data in Table 5 show very low hydraulic conductivities, nearly 4 orders of magnitude below that required for RCRA equivalence. No correlation between sample thickness and hydraulic conductivity was observed from these data. The likely reason is that $1 \times 10^{-11} \mathrm{~cm} / \mathrm{s}$ is the minimum hydraulic conductivity that can be measured with the current laboratory setup. Figure 11 shows the changes in hydraulic conductivity versus measurement duration for comparison with the prototype core samples. The relative variation with time is much less for these samples than that observed in the prototype cores. This is not unexpected since the membrane samples have much less porosity from which air bubbles can escape and affect measurements. 
Table 5. Hydraulic Conductivity of Fluid Applied Asphalt Membrane Samples from Prototype Barrier

\begin{tabular}{cccl} 
Sample & Thickness, $\mathbf{c m}$ & $\begin{array}{c}\text { Hydraulic } \\
\text { Conductivity, } \mathbf{c m} / \mathbf{s}\end{array}$ & \multicolumn{1}{c}{ Description } \\
\hline 1 & 0.160 & $1.36 \mathrm{E}-11$ & FAA applied to geofabric \\
2 & 0.265 & $1.18 \mathrm{E}-11$ & Sample taken on $5 / 15 / 94$ \\
3 & 0.275 & $2.49 \mathrm{E}-11$ & Sample taken from strip Z \\
4 & 0.500 & $2.51 \mathrm{E}-11$ & Sample taken from strip AA
\end{tabular}

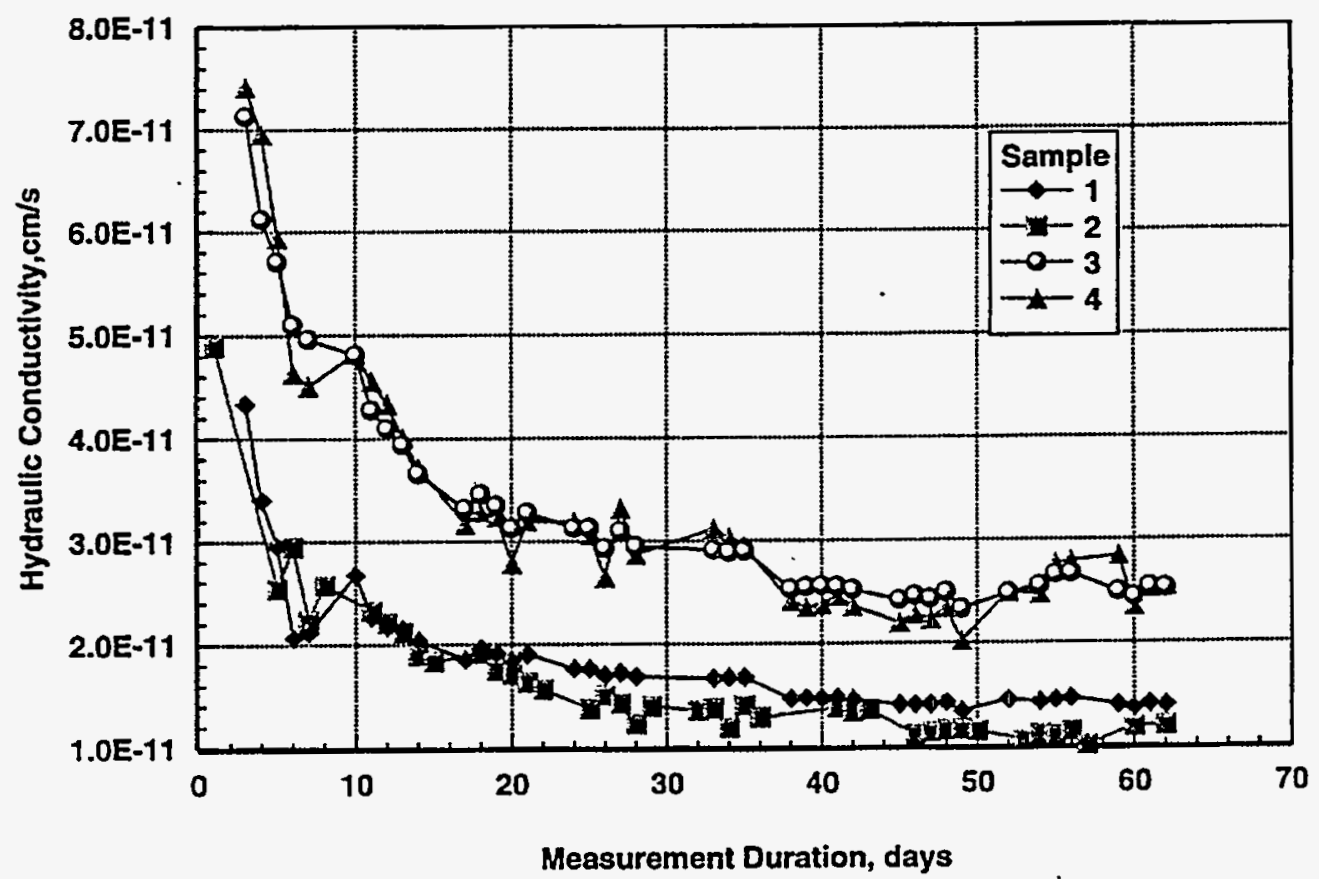

Figure 11. Change in Hydraulic Conductivity with Measurement Duration for FAA Samples

Laboratory HMAC Test Specimens. A series of laboratory HMAC test specimens were prepared to evaluate the effects of asphalt type and content on hydraulic conductivity. These specimens were prepared using standard Marshall mix design procedures (ASTM D-1559), resulting in a $10 \mathrm{~cm}$ diameter $\times 5 \mathrm{~cm}$ thick cylinder. These test specimens were sealed into the test cells shown in Figure 7 . The primary asphalt range of concern was $6.5 \mathrm{wt} \%$ to $8.0 \mathrm{wt} \%$, which brackets the range of asphalt contents expected to have the proper physical and hydraulic conductivity properties. A number of samples were tested using the constant head method for measuring hydraulic conductivity. Quantitative data were not obtained due to the lack of breakthrough of water through the sample after several months of testing. Samples were then retested using the falling head technique. The validity of these measurements was checked by measuring the hydraulic conductivity of a ceramic plate with a known hydraulic conductivity. Results of these measurements are presented in Table 6 and illustrated in Figure 12. 
Table 6. Hydraulic Conductivity Data for Laboratory Specimens

\begin{tabular}{ccc} 
Sample & $\begin{array}{c}\text { Asphalt Content, } \\
\text { wt\% }\end{array}$ & $\begin{array}{c}\text { Hydraulic } \\
\text { Conductivity, } \mathbf{c m} / \mathbf{s}\end{array}$ \\
\hline 023 & 6.5 & $3.30 \mathrm{E}-11$ \\
024 & 6.5 & $1.05 \mathrm{E}-11$ \\
025 & 6.5 & $6.96 \mathrm{E}-11$ \\
026 & 7.0 & $5.02 \mathrm{E}-11$ \\
027 & 7.0 & $6.57 \mathrm{E}-11$ \\
028 & 7.0 & $9.63 \mathrm{E}-11$ \\
014 & 7.5 & $7.27 \mathrm{E}-11$ \\
017 & 7.5 & $2.09 \mathrm{E}-12$ \\
018 & 7.5 & $6.37 \mathrm{E}-11$ \\
019 & 7.5 & $8.25 \mathrm{E}-11$ \\
021 & 7.5 & $4.63 \mathrm{E}-11$ \\
057 & 7.1 & $5.86 \mathrm{E}-11$ \\
058 & 7.1 & $9.28 \mathrm{E}-11$ \\
059 & 7.1 & $2.12 \mathrm{E}-10$ \\
15 bar ceramic plate & - & $2.55 \mathrm{E}-9$ \\
K $=2.59 \times 10^{-9} \mathrm{~cm} / \mathrm{s}$ & &
\end{tabular}

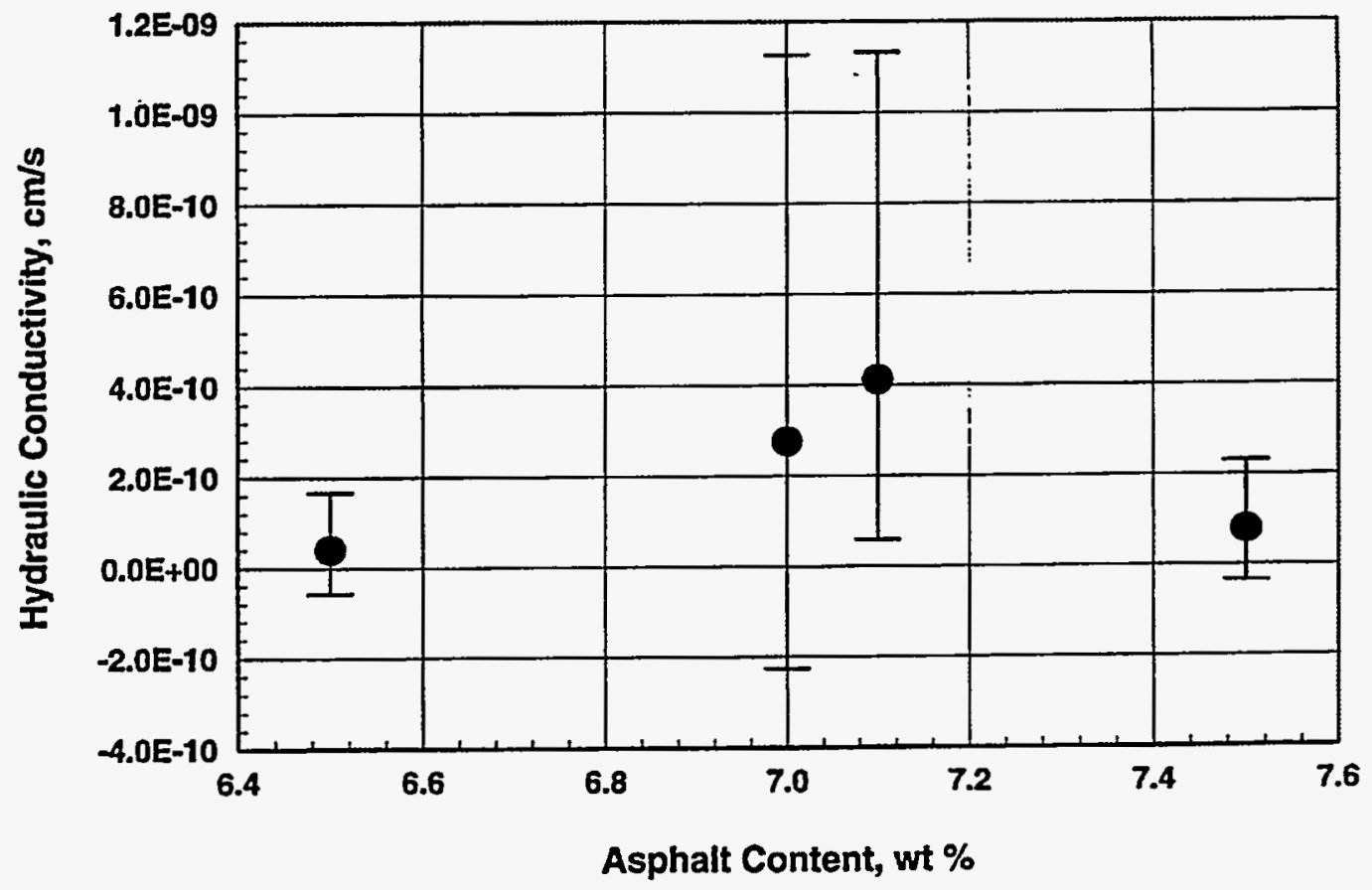

Figure 12. Hydraulic Conductivity vs. Asphalt Content for Laboratory Specimens 


\section{Asphalt Test Pad Monitoring}

The layout of the test asphalt pad showing the location of the buried water collection lysimeter and seams in the two layers is illustrated in Figure 13. The seams where adjacent passes of the paver come together are expected to be the area of highest hydraulic conductivity. This weakness should be minimized by the use of a two-layer system with seams overlapped by a minimum of $1.5 \mathrm{~m}$.

\section{Planned Testing}

A number of tests are planned during late FY 1994 and FY 1995 to document the performance of the HMAC layer. The primary method of determining hydraulic conductivity will be the use of the SDRIs. Two side-by-side tests are planned for the test pad over the time frame of September November 1994. One of the tests will be conducted directly over a seam in the top layer of the HMAC, while the second test will be performed in an area of the test pad that does not have a surface seam so that the relative importance of seams to the overall performance of the asphalt layer can be evaluated.

The SDRI tests will be conducted by Shannon and Wilson, Inc., through a contract with ICF Kaiser. The SDRIs are custom-built, square aluminum frames measuring $2.4 \mathrm{~m} \mathrm{x} 2.4 \mathrm{~m}$ for the outer ring and $0.9 \mathrm{~m} \times 0.9 \mathrm{~m}$ for the inner measurement area. The frames will be placed in grooves cut $10 \mathrm{~cm}$ deep for the outer ring and $5 \mathrm{~cm}$ for the inner measurement pan using a water-cooled concrete

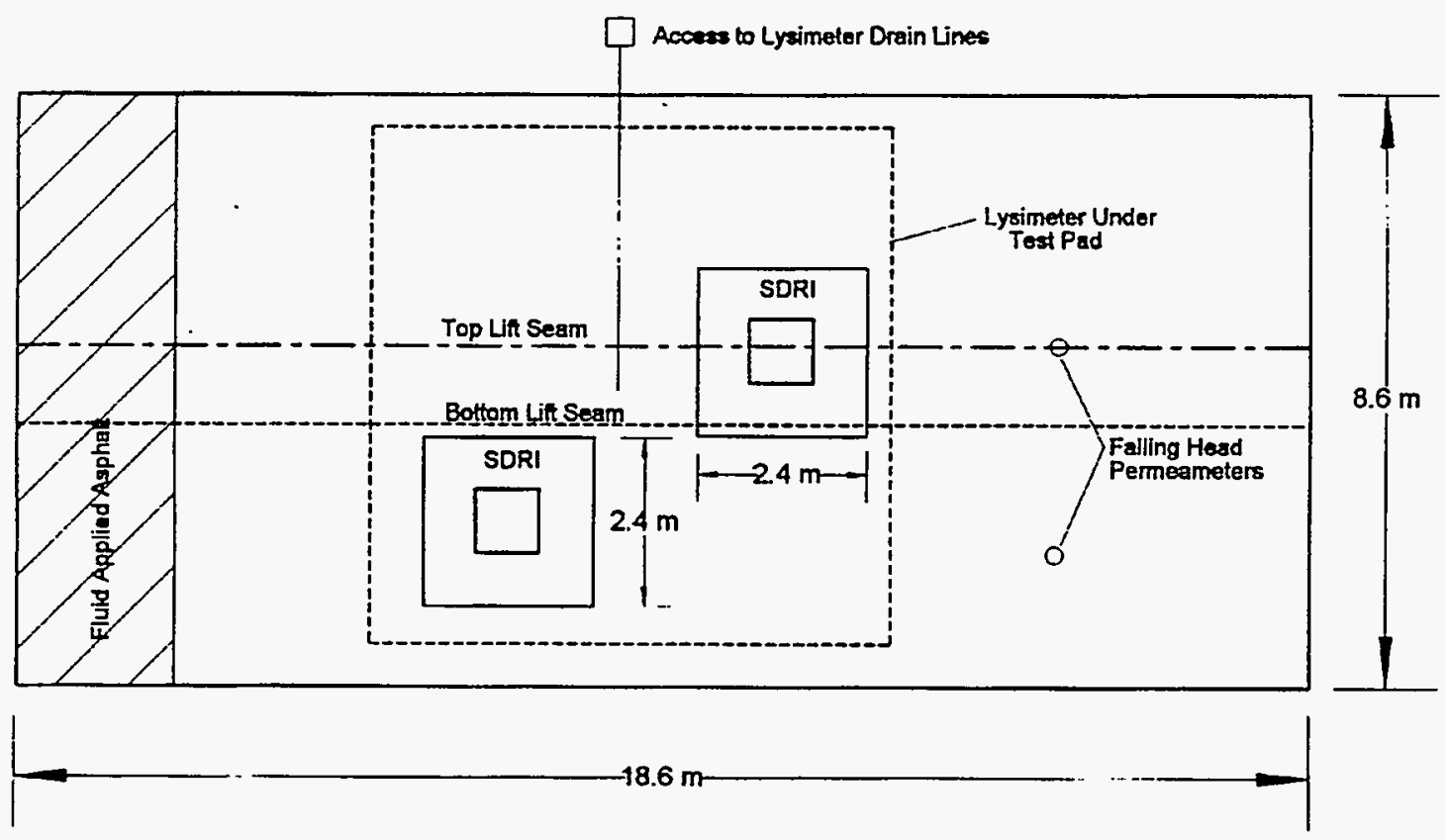

Figure 13. Construction Details and Measurement Locations on Asphalt Test Pad 
saw. The depth for the inner ring is based on being able to fully penetrate through the top course of asphalt and confine any lateral flow that might occur along the seam areas. The rings will be sealed into the grooves with bentonite grout, filled with water, and allowed to degas for several days. The water levels will then be adjusted and the SDRI covered to minimize evaporation. The change in water level in the inner pan will initially be monitored on a daily basis until equilibrium is approached. The infiltration of water from the inner ring will be monitored on a weekly basis after equilibrium is achieved. A report summarizing the results of the test is expected by the end of November 1994 .

The hydraulic conductivity of the test pad will also be monitored by two field falling head permeameters currently installed at the east side of the test pad (Figure 13). These permeameters will be monitored concurrently with the SDRIs.

After all hydraulic conductivity measurements are completed, the test pad will be available for destructive testing. A series of cores will be removed to determine lab permeability, asphalt content, aggregate size distribution, and bulk density. Additional samples may also be removed at a later date for use in testing for physical properties such as elastic and creep modulus and for seismic properties testing. 



\section{Baseline Asphalt Properties}

A number of experiments were performed to establish a baseline set of data for comparison to results from accelerated aging tests designed to simulate aging over the 1000-year design life of the barrier (Freeman and Romine 1994). Five asphalts were used: U.S. Oil and Refining AR-4000 asphalt, the asphalt specified for use in the prototype barrier, and four asphalts from the Strategic Highway Research Program - Materials Reference Library (SHRP-MRL) (AAG-1, AAD-1, AAK-1, and AAM-1). The asphalts in the SHRP-MRL were selected for use in this program because these four asphalts represent a wide variety of asphalt types available in North America and have been extensively characterized, chemically and physically, during the course of SHRP research.

AAG-1 and AAD-1 are AR-4000 graded asphalts manufactured from Central California crude sources, but have vastly different responses to accelerated aging conditioning. AAG-1 responds very well to aging conditions, while AAD-1 responds very poorly. AAG-1 was also selected from the SHRP-MRL because the crude oil used to produce this asphalt is in close proximity to the natural seeps that were the source for the Chumash Indian artifacts being studied in the asphalt analog work task.

The physical properties were determined on the asphalts used in this study before and after thin film oven test (TFOT) conditioning. TFOT conditioning is simulative of the aging that occurs to an asphalt cement during the course of mixing with aggregate in a hot-mix plant (ASTM D-1754). This conditioning will provide a true baseline data set, since the HMAC applied to the HPIB is manufactured by standard hot-mix plant procedures and will be exposed to aging conditions during manufacture. These analysis performed are as follows:

- Mass Change (loss of volatiles)

- Brookfield Viscosity (ASTM D-4402)

- Penetration (ASTM D-5).

The accelerated aging procedures were conducted in 40-mm-diameter steel pans (Table 7). This sample container is not the size cited in ASTM D-1754. This sample configuration was necessary because the pressure aging vessel prototype designed in the laboratory could not accommodate the larger $(140 \mathrm{~mm})$ sample pans. The mass change increase in viscosity were greater than those reported for SHRP asphalts conditioned according to the standard ASTM and SHRP accelerated aging procedures. However, the variance in the data was consistent and trends in the data were not affected.

The results of the baseline data for the analysis of the SHRP-MRL asphalts is consistent with that reported in the literature (SHRP-MRL 1991). Viscosity measurements reported in the literature were somewhat lower than those measured in this work (Table 8). One possible reason is that the 
Table 7. Mass Change After Thin Film Oven Test (TFOT) Conditioning

Mass Change, wt \%

\begin{tabular}{ccc} 
Asphalt & ASTM 140-mm Pans & 40-mm Pan \\
\hline AAD-1 & -0.983 & -1.188 \\
AAG-1 & -0.274 & -0.310 \\
AAK-1 & -0.627 & -0.715 \\
AAM-1 & 0.059 & 0.071 \\
AR-4000 & -0.298 & -0.242 \\
USAR-4000 & -0.219 & -0.319
\end{tabular}

Table 8. Asphalt Binder Viscosity as Measured with Brookfield Viscometer

\begin{tabular}{ccc} 
& \multicolumn{2}{c}{ Viscosity, cP } \\
Asphalt & Before TFOT & After TFOT \\
\hline AAD-1 & 1209 & 5262 \\
AAG-1 & 1974 & 3785 \\
AAK-1 & 4100 & \\
AAM-1 & 2118 & 6372 \\
ACME AR-4000 & 3473 & \\
U.S. OIL AR-4000 & 1407 & 3073
\end{tabular}

shear conditions for the Brookfield viscometer used in the PNL studies were different from those for the vacuum tube viscometers used in the SHRP studies. The variations were consistent, however, and the trends in the data were not changed.

HMAC samples were also included as part of the baseline data. These samples were manufactured with the U.S. Oil and Refining AR-4000 asphalt and aggregate used in the construction of the HPIB prototype (Table 9). The asphalt content for the HMAC samples was varied from $6.5 \mathrm{wt} \%$ to $8.0 \mathrm{wt} \%$ asphalt, while maintaining a normalized aggregate gradation. Baseline data, in the form of Marshall mix design analysis measuring lateral flow and maximum applied load, were obtained (Table 10). Indirect tensile strength (Table 11) was also determined for this set of mixtures. 
Table 9. Penetration (ASTM D-5) of Asphalt Binders

\begin{tabular}{ccc} 
Asphalt & \multicolumn{2}{c}{ Penetration, 0.1 mm } \\
Before TFOT & After TFOT \\
\hline AAD-1 & 129 & 63 \\
AAG-1 & 53 & 34 \\
AAK-1 & 69 & - \\
AAM-1 & 63 & 39 \\
ACME AR-4000 & 65 & 46 \\
U.S. OIL AR-4000 & 55 & 46
\end{tabular}

Table 10: Marshall Flow and Stability (U.S. Oil and Refining AR-4000)

Weight Percent Asphalt

6.5
7.0
7.5
8.0
Flow, $.01 \mathrm{~mm}$

208

188

222

292
Maximum Load, psi

2180

2024

1967

1681

Table 11. Indirect Tensile Strength (U.S. Oil and Refining AR-4000)

\begin{tabular}{cc} 
Weight Percent Asphalt & Maximum Load (psi) \\
\hline 6.5 & 1250 \\
7.0 & 1109 \\
7.5 & 940 \\
8.0 & 799
\end{tabular}





\section{Asphalt Analog Studies}

The primary objective of the asphalt analog studies is to use natural asphalt archaeological samples to establish the long-term durability of modern, manufactured asphalt materials used in the construction of the HPIB. Buried archaeological asphalt artifacts are analogous with the proposed asphalt impermeable component of the HPIB. Both were heated and intentionally formed within a short time before being sealed from light and most oxygen. The archaeological specimens remained buried until their discovery, often many centuries later. Archaeological asphalts are therefore expected to provide valuable information, not available from any other source, about the long-term aging behavior for buried asphalt and its effect on barrier performance.

The strategy to assess the long-term performance of asphalt was to acquire a dated series of archaeological asphalt artifacts, ranging in age from 500 to 4000 years, along with naturally occurring asphalt from the same vicinity. The asphalt artifacts and natural seep material were analyzed chemically to develop a better understanding of chemical reactions of asphalt during extremely long-term aging in a reduced oxygen environment and in the absence of ultraviolet radiation. The result will be a set of data that will be used to "calibrate" an accelerated aging process by which experimental samples (modern asphaltic materials used in the HPIB construction) will be conditioned to simulate long-term aging. The data gathered in these studies will be useful for evaluating the long-term stability and effectiveness of commercial asphalts proposed for use as barriers at Hanford.

\section{Background}

Wherever natural asphalt outcroppings occur, asphalt artifacts are found in archaeological deposits. The earliest recorded use of asphalt, which dates to 3250 B.C. ( $\sim 200$ B.P.), comes from the Mesopotamian and Indus civilizations of the Middle East (Forbes 1955). Asphalt was used as mortar, stucco, sealant, waterproofing agent, and embalming material. It was also an important trade and tribute item throughout the region. Accounts of early asphalt use from this region abound, primarily due to its availability.

Asphalt from Val de Travers in Switzerland was used by prehistoric lake dwellers as a preservative for underwater building supports (Nellensteyn 1938). There are numerous accounts of prehistoric asphalt use in North America, ranging from the famous "Seneca Oil" of the Seneca Indians of the northeastern United States (Giddens 1974) to Florida and Texas (Dedera 1976; De Vaca 1545), to the Mexican Gulf states of Tamaulipas and Vera Cruz, where asphalt was used as flooring in temple mounds 3000 years old (Muir 1926), to Utah and Wyoming (Dedera 1976).

Some of the best documented prehistoric accounts of asphalt use in North America come from the Santa Barbara Channel region of California, where its use was reported by early Spanish explorers (Fages 1775). Asphalt artifacts dating to 5000 years B.P. have been recovered from archaeological sites throughout the region (Moratto 1984; Gutman 1979, 1983; Heizer 1943; Rogers 1929). Many reported artifacts from the Santa Barbara Channel were found in graves, which makes them most suitable as analogs of a buried moisture barrier. 
Hellmuth (1989), who established the applicability and utility of using natural deposits of asphalt as an analog to asphalts used within waste containment environments, stated that the major problem with using archaeological samples in analog studies is the lack of information on the origin of the asphalt and its original composition, coupled with the problem of establishing what natural weathering and biodegradation has occurred to an item before and after its deposit into the archaeological record. These limitations will be addressed in the present study.

\section{Technical Approach}

The technical approach for identifying and characterizing asphalt archaeological samples is as follows:

1. Select a series of asphalt samples from archaeological sites in close proximity to natural asphalt seeps.

2. Obtain samples of unaltered or asphalt analog samples from nearby natural seeps.

3. Determine how long selected asphalt artifacts had been buried.

4. Establish that asphalt artifacts and natural asphalt are derived from the same petroleum deposit (sourcing).

5. Chemically analyze archaeological asphalt to determine the effects of long-term aging in a buried environment.

Each of the steps listed above is described in the following sections as well as the approach and background used to characterize a series of archaeological artifacts identified from the Santa Barbara, California, region.

\section{Selecting Archaeological and Neat Asphalt Samples}

To address Hellmuth's (1989) concerns, this study initially focused on one geographical area, the Santa Barbara Channel region, where methods for determining the source of an asphalt artifact have been extensively applied (Gutman 1979, 1983) and where detailed ethnographic accounts on asphalt processing methods are available (Hudson et al. 1978). Additionally, sample artifacts were limited to those recovered from burial assemblages. In this manner, primary internment of the artifact is established and the linkage with asphalt to be used for waste containment is strengthened because of the similarity in subsurface environments.

Santa Barbara Asphalt. The Chumash culture developed over a period of 7000 years along the east/west trending coastline which characterizes the Santa Barbara region (King 1981). The Chumash maintained vast trade networks and used a sophisticated monetary system driven by market forces (King 1981; Moratto 1984; Chartkoff and Chartkoff 1984; Willey 1966). Asphalt played a significant role in the manufacture of numerous art, craft, and utilitarian items. It was used to waterproof and preserve their large, oceangoing canoes; affix ornaments to jewelry, apparel, and specialized items; and to attach arrow points to shafts, knives to handles, baskets to mortars, and fish hooks to lines. 
Deposits of hardened asphalt were preferred over the softer float material which washed up onto the beaches and accumulated on the rocks (Hudson et al. 1978). Sometimes the asphalt, after being crushed and heated, was used without additives, although it was also mixed with pine pitch and ocher (Hudson et al. 1978).

The climate of the Santa Barbara region for the last 3000 to 4000 years can be described as Mediterranean, with wet, mild winters and dry, warm summers. Interior vegetation is typically scrub chaparral broken by oak groves and open grasslands studded with savannah-form live oaks.

Geologically the region is quite complex. The Santa Barbara Channel is a structural depression capped by sedimentary rocks of Miocene, Oligocene, and Eocene ages (Dibblee 1987). The rugged Santa Ynez Mountains rise to the north, past the narrow, 2 to 5 mile $(3.2$ to $4.8 \mathrm{~km})$ wide coastal plain. These coastal mountains are the result of a tectonic accretionary wedge and consist of a jumbled mix of metamorphic and sedimentary rocks (Dibblee et al. 1984). Numerous faults, trending northwest/ southeast, dissect the region. The reservoir rock for extensive oil, gas, and tar deposits is the Miocene Age Monterey formation, which is capped by quaternary and Pliocene sediments. Fractures within the cap rock account for the numerous seeps found throughout the region.

Selection of Archaeological Samples. Archaeological samples from the Santa Barbara Channel were obtained from collections at the Santa Barbara County Museum of Natural History; the University of California, Santa Barbara; and the University of California, Los Angeles. Sites from which samples were chosen have been characterized as prehistoric Chumash cemeteries which are in close proximity to known asphalt seeps and which have been excavated by the aforementioned institutions over the past 75 years. Since discovery, the artifacts have been housed in museum drawers and collection bags where they are not exposed to temperature extremes or light. An attempt will be made to obtain specimens of a wide range of presumed age and that are associated with other organic material that can be used for radiocarbon dating. Twenty-six asphalt specimens were obtained from the collections of the above-referenced institutions. The archaeological records suggested the artifacts range in age from 400 to 5000 years old.

Selection of Asphalt Analog Samples. Numerous major natural seeps of asphaltum occur in the Santa Barbara vicinity. At least $1 \mathrm{~kg}$ of asphalt, enough for source analysis and use in artificial aging experiments, was obtained from each of several source locations nearest the sampled archaeological sites. Where seep asphalts occurred in differing degrees of hardness, an effort was made to obtain examples of a range of conditions.

\section{Determining the Duration of Internment for Asphalt Artifacts}

The objective of this task is to establish how long asphalt artifacts, selected for study, were interned in a burial site. This was done in order to establish a link between the response of asphalt artifacts to aging in a depositional environment similar to that of the asphaltic components of the HPIB. Determining the duration of internment, or time underground, of the asphalt artifacts provides information for characterizing the chemical composition of the artifacts with a time reference. It was assumed that the changes in the chemistry of the asphalt artifacts can be directly correlated to how long an artifact has been buried. This provides a link showing that the changes in the chemical composition as a factor of time for an asphalt artifact is simulative of the changes expected in the asphaltic components of the HPIB. Achieving this objective required radiocarbon dating non-asphaltic artifacts to determine 
the duration of internment. Wherever possible, specimens of shell, bone, or wood charcoal reported to have been found in the same graves as selected asphalt artifacts were obtained from the museums and were radiocarbon dated. The most sought-after artifacts were those to which asphalt was found adhering or was found to be an integral part of the specimen.

It was assumed that the radiocarbon age of the artifacts is representative of the length of time that the asphalt artifacts have been buried in the grave sites. If objects from the same grave could not be obtained, specimens found nearby in the same geological layer were used. When asphalt was found adhering to an object to be dated, it was removed prior to radiocarbon dating by solvent extraction or mechanical means. Asphalt recovered by solvent extraction was recovered under low temperature and vacuum conditions to minimize oxidation.

\section{Sourcing the Asphalt Artifacts}

The susceptibility of asphalt to various aging mechanisms depends largely on the original chemical composition of the material (Branthaver et al. 1984; Tuffour et al. 1989). Chemical composition of asphalts varies greatly, depending on the diagenesis and catagenesis of source sediments and the organic source materials (Filby and Berkel 1986). Variations in the heteroatom content, aromatic to aliphatic carbon and hydrogen ratios, molecular size distribution, and amphoteric compound content have a profound impact on the chemical behavior of asphalt. The physical properties of an asphalt are also strongly influenced by its chemical composition (Branthaver et al. 1984; Predoehl and Kemp 1978; Petersen 1989; Tuffour et al. 1989). For example, the chemical composition will affect the way an asphalt or asphalt mixture responds to aging (accelerated or natural) and how it will respond to changes in its environment, such as heat, radiation, or moisture.

It is very important to identify which type of asphalt analog source (cliff seep or beach float) was used to manufacture the asphalt artifacts used in this study. This is important because it will help establish that the initial chemistries of the artifacts were similar and therefore subsequent chemical analysis can easily be compared. Elemental analysis was performed to determine the ratio of nickel to vanadium, which was used to verify that the asphalt artifacts were manufactured from materials collected from one or more of the asphalt seeps and, therefore, originally had the same chemical and physical characteristics as one of the sampled seeps. The $\mathrm{Ni} / \mathrm{V}$ ratio is a highly source-specific characteristic for petroleum products.

Nickel and vanadium concentrations were determined by inductively coupled plasma spectroscopy. The samples were digested in hydrochloric and nitric acid and the metals extracted into an aqueous solution for easy analysis.

\section{Chemical Analysis of Archaeological Asphalt to Determine the Effects of Aging}

Asphalt artifacts and samples obtained from the asphalt seeps were analyzed to provide data for estimating the rate and degree of chemical changes in the asphalt artifacts. Analog samples retrieved from the field were analyzed as controls. Deviations in the chemistry of the artifacts, relative to the analog control samples, were interpreted as changes attributable to long-term exposure to soil conditions. Two chemical procedures were performed on the analog and artifact samples: infrared spectroscopy (IR) and high pressure liquid chromatography-size exclusion chromatography (HPLC-SEC). IR analysis was performed qualitatively and quantitatively. 
Ethnographical records indicated that the Chumash used a number of different materials, pine pitch and ocher, for example, to modify asphalts used in different applications. Qualitative analysis was used to establish that the artifacts had not been modified by the Chumash with pine pitch; otherwise the applicability of the quantitative IR analysis would have been suspect. Analysis of artifacts associated with the construction of the Chumash sea-faring canoes shows evidence of extensive modification with pine pitch, but it was not used on the asphalt artifacts studied here.

Quantitative IR analysis was used to monitor changes in chemical functional groups as a result of the aging process. Functional group analysis was performed on the asphalt samples to specifically characterize the following products of oxidative aging: phenolic, pyrrolic, sulfoxide, carbonyl, ketone, carboxylic acid, and anhydride functionalities. The IR quantitative functional group analysis protocol that was used is described by Petersen (1986).

HPLC-SEC was used to measure changes in the molecular size distribution caused by condensation reactions and loss of volatiles. HPLC-SEC data were used to monitor the increase in the molecular size distribution as the result of oxidative aging. The HPLC-SEC method used is described by Jennings (1985).

\section{Results}

The asphalt analog studies have produced results from radiocarbon dating, elemental analysis, quantitative and qualitative IR analysis, and HPLC-SEC analysis.

\section{Radiocarbon Dating}

A series of artifacts were analyzed by radiocarbon dating. These artifacts ranged in age from 400 B.P. to 4160 B.P. Each of the radiocarbon dated artifacts either had asphalt adhering to it or had an asphalt artifact found in close association with it in the archaeological excavation. These data provide a direct link to when an asphalt artifact was interned in a burial site. Table 12 details the radiocarbon dating results. The reported dates have been adjusted by carbon- 13 .

Table 12. Radiocarbon Dates of Chumash Artifacts

\begin{tabular}{cc} 
Sample & C13 Adjusted Age, B.P. \\
\hline HCRL-1 & $1810 \pm 60$ \\
HCRL-2 & $1880 \pm 70$ \\
HCRL-3 & $400 \pm 50$ \\
HCRL-4 & $2030 \pm 70$ \\
HCRL-9 & $1160 \pm 50$ \\
HCRL-10 & $1510 \pm 60$ \\
HCRL-10a & $1400 \pm 60$ \\
HCRL-11 & $1970 \pm 70$ \\
HCRL-14 & $4160 \pm 100$
\end{tabular}


The results of these analyses show that the asphalt artifacts had been interned for a relatively short period of time ( 400 years), and several samples had been interned from two to four times the design criterion identified for the asphaltic components of the HPIB. The radiocarbon dating data allows the subsequent chemical analysis (IR and HPLC) data to be evaluated, in relation to a time-line associated with the duration of internment of the artifacts. Based on these results a time-line can be established stretching back more than 4000 years and forward to the present.

\section{Elemental Analysis}

The concentration of nickel and vanadium was determined for seven asphalt artifacts and five asphalt analog samples. The primary concern was to effectively establish that the asphalt analog samples were the starting materials used in the manufacture of the asphalt artifacts. Table 13 outlines the results of the nickel and vanadium analyses.

The most significant feature of these data is the ratio of nickel to vanadium. This ratio has been used extensively to identify the source of crude oils and petroleum products. The ratio of $\mathrm{Ni} / \mathrm{V}$ remains constant through processing and is independent of the concentration of insoluble materials (a feature common to natural asphalts and subsequently the artifacts) and the duration of internment at an archaeological site.

The $\mathrm{Ni} / \mathrm{V}$ ratio for the asphalt artifacts is very similar to those of the asphalt analog samples Analog-8, Analog-9, and Analog-26. These three analog samples are from active seeps in the area. This material is very similar in consistency to a hard, roofing-grade asphalt material. Ethnographic information suggests that this type of material was most commonly used for manufacturing various asphaltic artifacts. Analog samples Analog-5 and Analog-16 are much more like crude oil in consistency and have a much higher $\mathrm{Ni} / \mathrm{V}$ ratio. These results verify that the future work developing an accelerated aging procedure should utilize seep materials found on the cliffs near Santa Barbara and not the liquid materials which float up onto the beach.

Table 13. Elemental Analysis of Asphalt Analog and Artifact Samples

\begin{tabular}{cccc} 
Sample & Nickel, ppm & Vanadium, ppm & Ni/V \\
\hline HCRL-1 & 110 & 370 & 0.29 \\
HCRL-2 & 97 & 300 & 0.32 \\
HCRL-3 & 100 & 360 & 0.28 \\
HCRL-4 & 74 & 230 & 0.32 \\
HCRL-6 & 86 & 210 & 0.41 \\
HCRL-9 & 110 & 330 & 0.33 \\
HCRL-12 & 42 & 110 & 0.38 \\
Analog-5 & 2.7 & 5.2 & 0.52 \\
Analog-8 & 110 & 270 & 0.40 \\
Analog-9 & 110 & 350 & 0.31 \\
Analog-16 & 8.2 & 13 & 0.63 \\
Analog-26 & 85 & 230 & 0.37
\end{tabular}




\section{Qualitative IR Analysis}

As discussed earlier, the qualitative analysis was conducted to determine if the Chumash had used pine pitch to modify the asphalt artifacts, because functionalities present in pine pitch would interfere with the quantitative analysis. IR spectra were obtained for a sample of pine pitch collected at Coal Oil Point, one of the sites where asphalt analog samples were collected in the field. The spectra were compared to several of the artifact spectra. Figure 14 shows the spectra of an artifact overlayed with that of the pine pitch. There is a strong absorbance at $1275 \mathrm{~cm}^{-1}$ in the pine pitch sample, which is not present in the artifact. None of the artifacts analyzed showed any evidence that they were modified with pine pitch. An asphalt analog sample, Coal Oil Point (fresh float), was modified in the laboratory with $1 \%$ (wt/wt) pine pitch. The reference absorbance for the pine pitch, $1275 \mathrm{~cm}^{-1}$, was clearly detectable at this low level.

\section{Quantitative IR Analysis}

Quantitative IR functional group analysis was performed on four asphalts from the SHRP Materials Reference Library (SHRP-MRL) asphalt artifacts, and asphalt analog samples. Asphalts from the SHRP-MRL were analyzed to provide reference data for the analysis. The functional group analysis of asphalt samples to specifically characterize the products of oxidative aging (phenolic, pyrrolic, sulfoxide, carbonyl, ketone, carboxylic acid, and anhydride functionalities) is lengthy and difficult to perform. The procedure is based on performing a number of different derivitization reactions which selectively consume a specific functionality in the asphalt. IR spectra are taken before and after the derivitization reactions, and the difference in the spectra provides a quantitative measurement of the

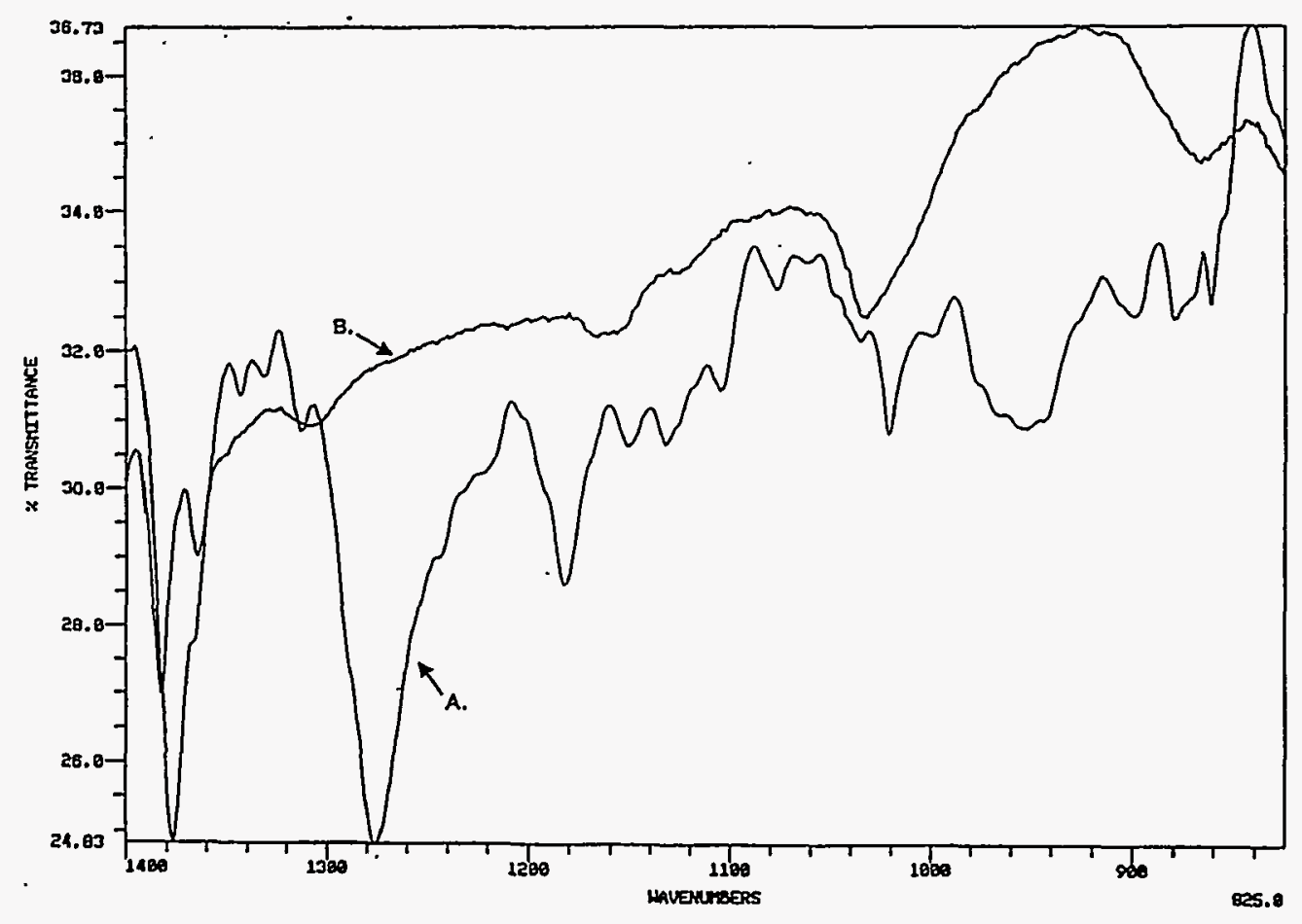

Figure 14. Qualitative IR Analysis 
concentration of the functionality. The derivitization reactions have been performed and IR spectra have been obtained for all of the SHRP-MRL asphaits, asphalt artifact, and asphalt analog samples.

The remaining effort for this task is primarily focused on analyzing the data generated in the analysis. A large number of model compounds must be analyzed to accurately calibrate the IR bench. The model compounds have been analyzed and the response factors calculated. It is anticipated that the data analysis will be completed by the end of FY 1994 or early FY 1995 . The results of these data will be analyzed relative to the ages established by radiocarbon dating. This should establish changes in chemistry over extremely long periods of time.

\section{HPLC-SEC Analysis}

As asphalt ages, its average molecular size increases due to polycondensation reactions. Polycondensation reactions are largely the result of oxidative coupling reactions, which combine smaller molecular weight materials into larger molecules. This increase in molecular size is one of the primary factors in age hardening (or embrittlement) of asphaltic materials. This behavior is especially important in the context of long-term durability, since the aged materials would be more susceptible to cracking.

Increases in the molecular size of the materials result in changes in the HPLC-SEC chromatogram. These changes can be easily quantified. Large molecular size (LMS) materials are the first to elute in SEC separations, so as an asphalt ages it is predicted that the area percent of the LMS region of a chromatogram should increase. HPLC-SEC separation was developed and performed on four SHRP-MRL asphalts, asphalt artifacts, and asphalt analog samples. The chromatograms were bi-modal with various shoulders present. Figure 15 illustrates the difference between the LMS region of three

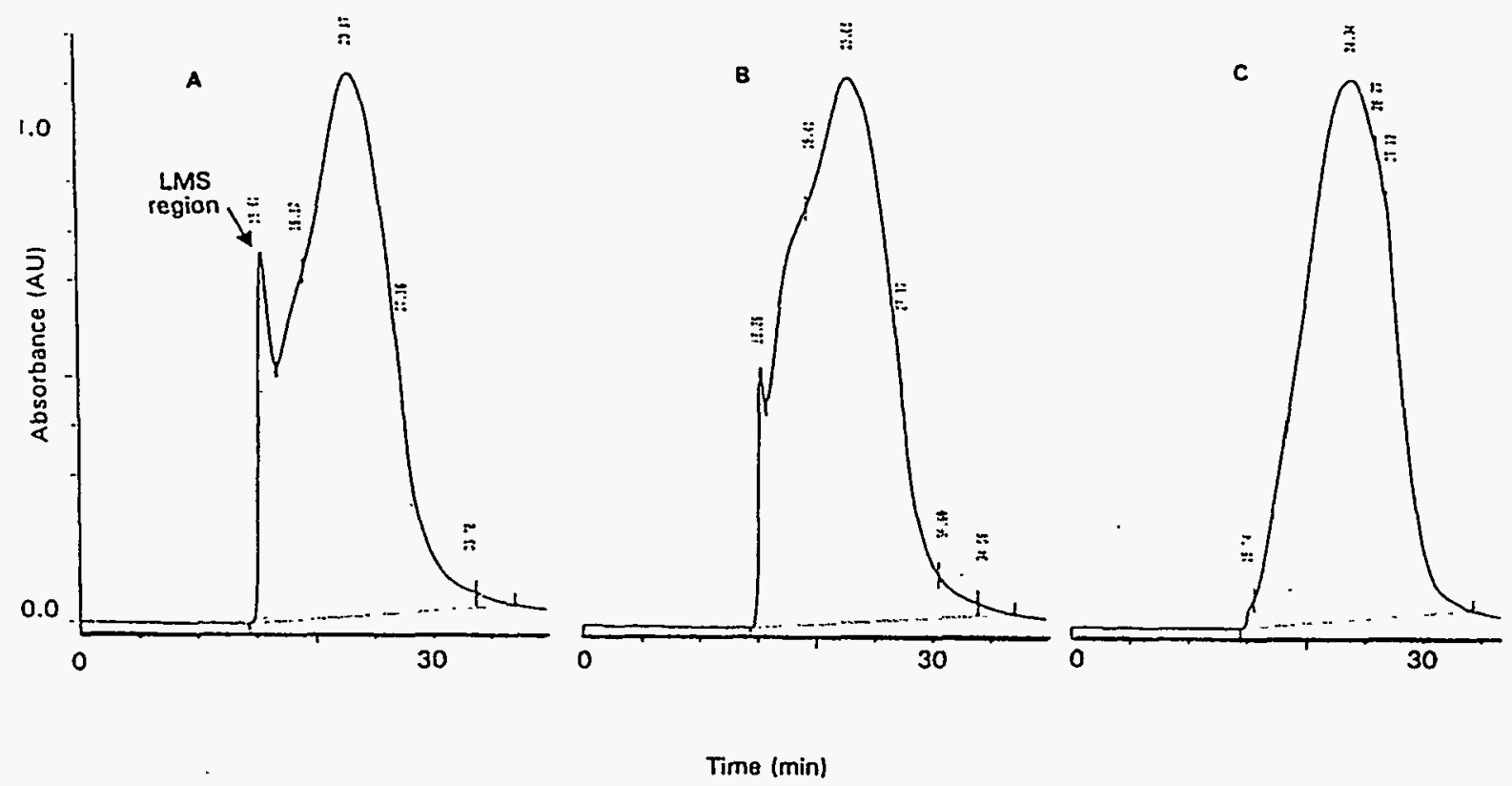

Figure 15. HPLC-SEC Chromatogram 
specimens: 1) artifact sample HCRL-14 (4160 B.P. \pm 100 years) and 2) artifact sample HCRL-10 (1510 B.P. \pm 60 years, and 3) analog sample Analog-9 (collected in the field at an active cliff seep). The LMS region increases in area percent as a function of age. The LMS region for the analog sample is extremely small, relative to the artifacts, and represents the time zero data point.

Jandel Scientific-Peak Fit software was used to quantify the HPLC-SEC chromatograms generated from the analysis of the asphalt samples. This software has excellent subroutines for the deconvolution of complex chromatograms. Peaks in the chromatograms exhibited good symmetry, so it was decided to keep the peak fit model as simple as possible. Therefore, an area Gaussian model was utilized in the analysis.

For the HPLC-SEC analysis of the asphalt artifacts and asphalt analogs, the area percent of the first peak (which represents the LMS) was quantified and plotted versus the duration of internment (based on radiocarbon dating) of the artifact. This analysis provides the first direct representation of how the buried asphalt artifacts change in chemical composition as a function of time (from present time to 4160 years B.P.). Figure 16 details the results of this analysis. This information is of great importance because it provides the first insights into a physical properties model for the long-term aging of asphalt and how it will function as a part of the HPIB. Based on this analysis, a clear relationship between the increase in the LMS as a function of duration of internment of the asphalt artifacts was established. The data. provided by this analysis, along with the quantitative IR analysis data, will be used to "calibrate" the accelerated aging procedure being developed as part of the asphalt technology development.

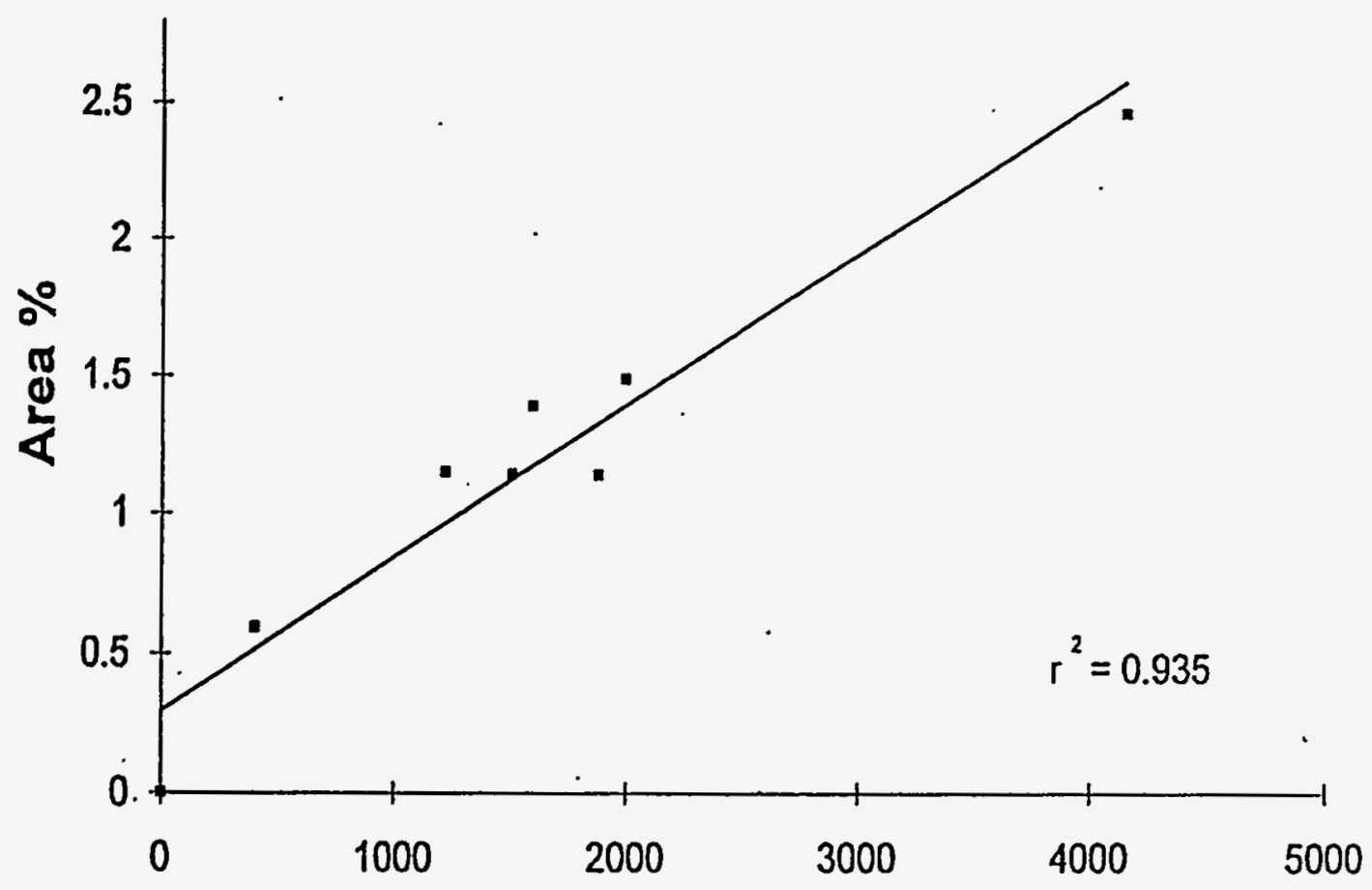

Figure 16. LMS vs. Age of Internment 


\section{Conclusions}

The following conclusions were drawn from the asphalt analog study:

- The age of internment for the asphalt artifacts was determined by performing radiocarbon dating of wood, shell, or bone artifacts which were in intimate contact with asphalt artifacts or were found to be in close association (within the excavation) with the asphalt artifacts.

- Radiocarbon dating showed that the artifacts range in age from 400 B.P. to 4160 B.P. (more than four times longer than the current design life of the HPIB).

- Elemental analysis was performed on a collection of asphalt artifact and asphalt analog samples. The results showed strong evidence that the artifacts were most likely manufactured from the asphalt analog samples collected in the field. This provides a clear link for comparing the chemical analysis of the asphalt artifacts to those of asphalt analog samples to be used in developing an accelerated aging procedure.

- Qualitative IR analysis showed that the asphalt artifacts used in this study were not modified with pine pitch, which would have caused problems for performing quantitative IR analysis.

- Several SHRP-MRL asphalts were analyzed using quantitative functional group analysis by IR. The results of these analyses agreed well with data reported in SHRP literature.

- All of the appropriate derivitization reactions, for quantitative functional group analysis by IR, were performed on the asphalt artifacts and asphalt analog samples. Analysis of the data to quantify the various functional groups is ongoing.

- HPLC-SEC analysis of the asphalt artifacts and asphalt analogs, using radiocarbon dating data, clearly establishes a relationship between the increase in the LMS as a function of duration of internment of the asphalt artifacts.

\section{Activities for FY 1995}

Efforts in FY 1995 will be focused on establishing the relationship between the chemistry of the asphait artifacts and asphalt analog samples, analyzed in FY 1994, and asphalt analog samples that have been exposed to accelerated aging conditions. These experiments will provide the crucial set of data for verifying the approach used to develop the accelerated aging procedure for simulating long-term aging conditions for the HPIB.

Asphalt analog samples will be exposed to a range of increasingly severe accelerated aging conditions. Quantitative IR functional group analysis and HPLC-SEC characterization will be performed on the conditioned samples. The chemical changes in the asphalt analog samples resulting from age conditioning will be compared with the results obtained from the analysis of the asphalt artifacts to establish the proper conditions necessary to simulate various degrees of aging. 
Sufficient quantities of the asphait analog samples will be age conditioned to perform physical properties analysis. Dynamic mechanical analysis (DMA) and hydraulic conductivity measurements will be performed to establish the performance characteristics of the barrier materials after simulated aging. DMA results will provide an insight to the long-term durability of the asphalt components of the HPIB. This is particularly significant to determining the response of the asphalt impermeable layer to waste form subsidence and seismic events.

Efforts will continue to identify additional sources of asphalt artifacts and asphalt analog samples to help establish the validity of the experimental approach and current results. Several potential sources were identified in FY 1994 and initial contacts were made to determine if these sources would be useful. Two sources were identified that hold promise for providing a second (possibly third) set of artifacts and analog samples. The first is located in Trinidad-Tobago. The Trinidad Lake Asphalt (TLA) Company has been operating for nearly 100 years. Ample analog samples are available from this site. The curator of the Trinidad National Museum, Ms. Claire Broadbridge, was contacted in FY 1994. She has provided information regarding the use of TLA in antiquity and the location and description of a number of museum collections holding artifacts manufactured using TLA. We will continue to pursue this relationship with the Trinidad National Museum and attempt to secure artifacts in FY 1995. The second potential source of artifacts is from the University of Pennsylvania. The curator of the Near East Collection has been contacted to determine if articles in the collection would be suitable for this study. 


\section{References}

ASTM D-5, Standard Test Method for Penetration of Bituminous Materials, ASTM Committee D-4 on Road and Paving Materials, April 1986.

ASTM D-1559, Resistance to Plastic Flow of Bituminous Mixtures Using Marshall Apparatus. American Society for Testing and Measure, ASTM Committee D 4 on Road and Paving Materials, December 1989.

ASTM D-1754, Effect of Heat and Air on Asphaltic Materials (Thin-Film Area Test), ASTM Committee D-4 on Road and Paving Materials, January 1988.

ASTM D-2041, Standard Test Method for Theoretical Maximum Specific Gravity and Density of Bituminous Paving Mixtures, ASTM Committee D-4 on Road and Paving Materials, September 1991.

ASTM D-4402, Standard Test Method for Viscosity Determinations of Unfilled Asphalts Using the Brookfield Thermosel Apparatus, ASTM Committee D-8 in Roofing, Waterproofing, and Bituminous Materials, February 1987.

Branthaver, J. F., M. Nazir, J. C. Petersen, S. M Dorrence, and M. J. Ryan. 1984. The Effect of Metalloporphyrins on Asphalt Oxidation (The Effect of Vanadyl Chelates Found in Petroleum). Liquid Fuels Technology 2:67-89.

Buelt, J. L., V. Q. Hale, S. M. Barnes, and D. J. Silviera. 1981. An Evaluation of Liners for a Uranium-Mill Tailings Disposal Site - A Status Report. PNL-3679, Pacific Northwest Laboratory, Richland, Washington.

Chartkoff, J. L., and K. K. Chartkoff. 1984. The Archaeology of California. Stanford University Press, Stanford, California.

Dedera, D. 1976. Petroleum and the American Indians. Exxon, USA 15(3):17-21.

DeVaca, Alvar Nunez Cabeza. 1545. The Journey of Alvar Nunez Cabeza De Vaca and His Companions from Florida to the Pacific, 1528-36. Translated and edited by A. F. Bandelier in 1905. New York.

Dibblee, T. W., Jr. 1987. Geologic Map of the Goleta Quadrangle. Division of Mines and Geology, Sacramento, California. United States Geological Survey, Denver, Colorado.

Dibblee, T. W., Jr., R. L. Johnson, J. W. Earley, and R. F. Meyer. 1984. Field Trip Guidebook: Geology and Hydrocarbon Deposits of the Santa Maria, Cuyama, Taft-McKittrick, and Edna Oil Districts, Coast Ranges, California. In Exploration for Heavy Crude Oil and Natural Bitumen, R. F. Meyer ed. AAPG Studies in Geology \#25, Tulsa, Oklahoma.

Fages, P. 1775. A Historical, Political, and Natural Description of California. Translated by H. I. Priestly. Reprinted in 1972 by Ballena Press, Ramona, California. 
Filby, R. H., and G. J. Berkel. 1986. Geochemistry of Metal Complexes in Petroleum, Source Rocks and Coals: An Overview. American Chemical Society Symposium Series 344:2-39.

Forbes, R. J. 1955. Studies in Ancient Technology, Vol. 1. E. J. Brill, Leiden, Netherlands.

Freeman, H. D., and R. A. Romine. 1994. Hanford Permanent Isolation Barrier Program: Asphalt Technology Test Plan. PNL-9336, Pacific Northwest Laboratory, Richland, Washington.

Gee, G. W., M. D. Campbell, H. D. Freeman, and J. F. Cline. 1989. Assessment of Cover Systems at the Grand Junction, Colorado Uranium Mill Tailings Pile: 1987 Field Measurements. PNL-6762, Pacific Northwest Laboratory, Richland, Washington.

Gee, G. W., et al. 1993. Testing and Monitoring Plan for the Permanent Isolation Surface Barrier Prototype. PNL-8391, Pacific Northwest Laboratory, Richland, Washington.

Giddens, P. H. 1974. The Early Petroleum Industry. Porcupine Press, Philadelphia.

Gutman, T. E. 1979. The Use of Asphaltum Sourcing in Archaeology. Journal of New World Archaeology 3:32-43.

Gutman, T. E. 1983. Additional Notes on Asphaltum Sourcing. Journal of New World Archaeology $5(3): 20-26$.

Hartley, J. N., et al. 1981. Asphalt Emulsion Sealing of Uranium Mill Tailings - 1980 Annual Report. PNL-3752, DOE/UMT-0201, Pacific Northwest Laboratory, Richland, Washington.

Heizer, R. F. 1943. Aboriginal Use of Bitumen by the California Indians. California Bureau of Mines Bulletin 118:74. Sacramento, California.

Hellmuth, K-H. 1989. Natural Analogues of Bitumen and Bituminized Radioactive Wastes. Säteilyturvakeskus, Strålsäkerhetscentralen Finnish Centre for Radiation and Nuclear Safety. Stuk-B-Valo 58, July 1989.

Hudson, T., J. Timbrook, and M. Rempe (eds). 1978. Tomol: Chumash Watercraft as Described in the Ethnographic Notes of John P. Harrington. Ballena Press/Santa Barbara Museum of Natural History.

Jennings, P. W. 1985. HPLC-GPC Analysis of Asphalt Cements. In Proceedings of the Association of Asphalt Paving Technologist 54:635.

King, C. D. 1981. The Evolution of Chumash Society: A Comparative Study of Artifacts Used in Social System Maintenance in the Santa Barbara Channel Region Before A.D. 1804. Phd. dissertation. Department of Anthropology, University of California, Davis.

Moratto, M. J. 1984. California Archaeology. Academic Press, New York. 
Muir, J. M. 1926. Data on the Structure of Pre-Columbian Huastec Mounds in the Tampico Region. Journal of the Royal Anthropological Institute of Great Britain and Ireland 56:231-238.

Nellensteyn, F. J. 1938. Bitumen, Ein Verfestigungsmaterial fur Radioaktive Abfalle und Seine Historischen Analoga. Technischer Bericht NTB 83:11. Baden.

Periasamy, R., J. R. Newsome, A. L. Andrady, and D. S. Ensor. 1990. Gas Permeability Measurements on Asphalt Using the Electrodynamic Balance. Symposium on Chemistry and Characterization of Asphalt, Division of Petroleum Chemistry 35:503-510, American Chemical Society, Washington, D.C.

Petersen, J. C. 1986. Quantitative Functional Group Analysis of Asphalt Using Differential Infrared Spectrometry and Selective Chemical Reactions-Theory and Application. Transportation Research Record No. 1096.

Petersen, J. C. 1989. A Thin-Film Accelerated Aging Test for Evaluating Asphalt Oxidative Aging. In Proceedings of the Association of Asphalt Paving Technologists 57:234-248.

Predoehl, N. H., and J. R. Kemp. 1978. An Investigation of the Effectiveness of Asphalt Durability Tests Report No. FHWA-CA-TL-78-26, California Department of Transportation, Sacramento, California.

Rogers, D. B. 1929. Prehistoric Man on the Santa Barbara Coast. Santa Barbara Museum of Natural History, Santa Barbara, California.

Strategic Highway Research Program - Materials Reference Library (SHRP-MRL). 1991. MRL Asphalt Properties. Transportation Research Record, Washington, D.C.

Terrel, R. L. 1991. Polymer-modified Hot-mix Asphalt for Environmental Liners. Hot Mix Asphalt Technology. Spring 1991:14-17:

Tuffour, Y. A., and I. Ishai. 1990. The Diffusion Model and Asphalt Age-hardening. Association of Asphalt Paving Technologist 59:73-92.

Tuffour, Y. A., I. Ishai, and J. Craus. 1989. Relating Asphalt Aging and Durability to Its Compositional Changes. In Proceedings of the Association of Asphalt Paving Technologists 57:201-224.

Willey, G. R. 1966. An Introduction to American Archaeology: Vol. I, North and Middle America. Prentice-Hall, Inc., Englewood Cliffs, New Jersey.

Wing, N. R. 1993. Permanent Isolation Surface Barrier: Functional Performance. WHC-EP-0650, Westinghouse Hanford Company, Richland, Washington. 


\section{Distribution}

No. of

Copies

Offsite

12 DOE/Office of Scientific and Technical Information

C. S. Abrams Argonne National Laboratory

P.O. Box 2528

Idaho Falls, ID 83401

2 Battelle Memorial Institute

Project Management Division

505 King Avenue

Columbus, OH 43201

ATTN: W. A. Carbeiner

Technical Library

D. E. Daniel

University of Texas

Dept. of Civil Eng.

Austin, TX 78712

R. C. Letcher

U.S. Department of Energy

Morgantown Energy Technology

Center

P.O. Box 880

Morgantown, WV 26505

C. Massimino

U.S. Environmental Protection

Agency

1200 Sixth Avenue

Seattle, WA 98101
No. of

Copies

J. Rensel

Washington State Department of Ecology

High-Level Waste Management

Mail Stop PV-11

Olympia, WA 98504

3 U.S. Department of Energy

785 DOE Place

Idaho Falls, ID 83402

ATTN: O. D. Markham

R. C. Morris

T. E. Reynolds

3 U.S. Department of Energy

Savannah River Operations

Office

P.O. Box A

Aiken, SC 29801

ATTN: W. J. Brumley

D. Bruegennjohann

2 U.S. Environmental Protection Agency

Hanford Project Office

712 Swift, MS B5-01

Richland, WA 99352

ATTN: D. A. Faulk

P. S. Innis

2 U.S. Geological Survey

1201 Pacific Ave., Suite 600

Tacoma, WA 98402

ATTN: W. R. Bidlake

B. W. Drost

Dist. 1 
No. of

Copies

2 Washington State Department of Ecology

7601 W. Clearwater, Suite 102

Kennewick, WA 99336

ATTN: D. Teal

N. Uziemblo

3 Washington State Department of Ecology

Mail Stop PV-11

Olympia, WA 98504-8711

ATTN: E. M. Carlin

C. Cline

R. B. Hibbard

2 Westinghouse Savannah River Company

P.O. Box A

Aiken, SC 29801

S. R. McMullin

M. G. Serrato

\section{Onsite}

\section{DOE Richland Operations}

G. J. Bracken

J. J. Broderick

A4-02

R. D. Freeberg

R. E. Gerton

J. D. Goodenough

A. C. Harris

R. D. Izatt

P. M. Pak

R. K. Stewart

D. E. Trader

DOE-RL Reading Room

2 U.S. Army Corps of Engineers

W. L. Greenwald

J. H. Jacobson
No. of

Copies

4 ICF Kaiser

S. D. Consort E6-31

D. L. Fort E6-50

L. A. Gladdis G7-57

R. I. Watkins E6-41

39 Westinghouse Hanford Company

M. R. Adams H6-01

H. Babad R2-78

R. J. Bliss B3-04

M. A. Buckmaster H6-03

J. W. Cammann H4-14

R. A. Carlson H6-03

C. C. Chamberlain H6-28

A. P. Church H6-28

H. D. Downey H6-27

W. F. Heine B3-63

C. E. Hodge A5-56

R. W. Hookfin H6-28

G. W. Jackson H6-21

K. N. Jordan H6-28

C. J. Kemp H4-14

M. K. Korenko B3-08

D. S. Landeen H4-14

M. J. Lauterbach H6-01

R. E. Lerch B3-63

H. E. McGuire B3-63

D. R. Meyers SO-14

D. J. Newland B1-58

K. L. Petersen H4-14

R. W. Powell H4-14

R. C. Roos H6-04

M. R. Sackschewsky H4-14

W. A. Skelly H6-03

J. C. Sonnichsen H4-14

J. A. Voogd R4-03

G. G. Williamson R4-01

N. R. Wing H4-14

T. M. Wintczak H6-27

D. E. Wood HO-32

Dist.2 
No. of

Copies

J. G. Woolard

Publishing Services (3)

Environmental Data Management Center (2)

\section{Pacific Northwest Laboratory}

E. G. Baker

L. L. Cadwell

M. D. Campbell

J. L. Downs

M. J. Fayer

D. Felmy

M. G. Foley

H. D. Freeman (10)

S. R. Gano

G. W. Gee

M. J. Graham
P8-38

P7-54

K6-77

P7-54

K6-77

K6-77

K6-84

P8-38

P8-38

K6-77

K6-78
No. of

Copies

C. T. Kincaid

K6-77

R. R. Kirkham

K6-77

G. V. Last

M. W. Ligotke

K6-84

P7-54

S. O. Link

T. L. Page

P7-54

K1-37

J. C. Ritter

K6-77

M. L. Rockhold

K6-77

L. E. Rogers

R. A. Romine (5)

P7-54

P8-38

P7-54

K6-77

R. L. Skaggs

M. E. Thiede

J. M. Thomas

K6-13

P7-54

K6-06

A. H. Zacher

Publishing Coordination

Technical Report Files (5)

K3-75 